Article

\title{
Collaborative Immersive Virtual Environments for Education in Geography
}

\author{
Čeněk Šašinka ${ }^{1} \mathbb{D}$, Zdeněk Stachoň $^{2, *} \mathbb{0}$, Michal Sedlák ${ }^{3, *} \mathbb{0}$, Jiří Chmelík ${ }^{4, * \mathbb{D}}$, Lukáš Herman ${ }^{2}$, \\ Petr Kubíček ${ }^{2}{ }^{1}$, Alžběta Šašinková ${ }^{1,5}$, Milan Doležal ${ }^{4}$, Hynek Tejk1 ${ }^{3}$, Tomáš Urbánek ${ }^{3}$, \\ Hana Svatoňová ${ }^{6}$, Pavel Ugwitz ${ }^{2,7}$ and Vojtěch Juřík ${ }^{3,7}$ \\ 1 Division of Information and Library Studies, Faculty of Arts, Masaryk University, 60200 Brno, Czech \\ Republic; cenek.sasinka@mail.muni.cz (Č. ̌̌.); st.betty@mail.muni.cz (A.̌̌.) \\ 2 Department of Geography, Faculty of Science, Masaryk University, 61137 Brno, Czech Republic; \\ herman.lu@mail.muni.cz (L.H.); kubicek@geogr.muni.cz (P.K.); 172577@mail.muni.cz (P.U.) \\ 3 Department of Psychology, Faculty of Arts, Masaryk University, 60200 Brno, Czech Republic; \\ 449327@mail.muni.cz (H.T.); tour@mail.muni.cz (T.U.); jurik.vojtech@mail.muni.cz (V.J.) \\ 4 Department of Visual Computing, Faculty of Informatics, Masaryk University, 60200 Brno, Czech Republic; \\ legacycz@mail.muni.cz \\ 5 Department of Psychology, Faculty of Social Studies, Masaryk University, 60200 Brno, Czech Republic \\ 6 Department of Geography, Faculty of Education, Masaryk University, 60300 Brno, Czech Republic; \\ svatonova@mail.muni.cz \\ 7 HUME Lab, Faculty of Arts, Masaryk University, 60200 Brno, Czech Republic \\ * Correspondence: zstachon@geogr.muni.cz (Z.S.); m.sedlak@mail.muni.cz (M.S.); \\ jchmelik@mail.muni.cz (J.C.); Tel.: +420-549-494-925 (Z.S.); +420-549-494-382 (J.C.)
}

Received: 5 November 2018; Accepted: 18 December 2018; Published: 23 December 2018

check for updates

\begin{abstract}
Immersive virtual reality (iVR) devices are rapidly becoming an important part of our lives and forming a new way for people to interact with computers and each other. The impact and consequences of this innovative technology have not yet been satisfactory explored. This empirical study investigated the cognitive and social aspects of collaboration in a shared, immersive virtual reality. A unique application for implementing a collaborative immersive virtual environment (CIVE) was developed by our interdisciplinary team as a software solution for educational purposes, with two scenarios for learning about hypsography, i.e., explanations of contour line principles. Both scenarios allow switching between a usual 2D contour map and a 3D model of the corresponding terrain to increase the intelligibility and clarity of the educational content. Gamification principles were also applied to both scenarios to augment user engagement during the completion of tasks. A qualitative research approach was adopted to obtain a deep insight into the lived experience of users in a CIVE. It was thus possible to form a deep understanding of very new subject matter. Twelve pairs of participants were observed during their CIVE experience and then interviewed either in a semistructured interview or a focus group. Data from these three research techniques were analyzed using interpretative phenomenological analysis, which is research method for studying individual experience. Four superordinate themes—with detailed descriptions of experiences shared by numerous participants-emerged as results from the analysis; we called these (1) Appreciation for having a collaborator, (2) The Surprising "Fun with Maps", (3) Communication as a challenge, and (4) Cognition in two realities. The findings of the study indicate the importance of the social dimension during education in a virtual environment and the effectiveness of dynamic and interactive $3 \mathrm{D}$ visualization.
\end{abstract}

Keywords: immersive virtual reality; collaborative immersive virtual environment; immersion; sense of presence; telepresence; Head-mounted display; cyberpsychology; human-computer interaction; collaborative learning; hypsography; contour lines; map literacy 


\section{Introduction}

Recent rapid and continuous development of immersive VR technology has opened the possibility for a wide range of applications. Decreasing prices and easy accessibility are factors helping to distribute these devices to different institutions as well as regular households. Immersive VR finds a purpose in many fields, for example, in psychotherapy and diagnostics [1-4], cognitive training $[5,6]$, relaxation $[7,8]$, rehabilitation $[9,10]$, medicine [11,12], training in the industry [13-15], tourism and cultural heritage [16-18], journalism [19], and sport [20,21]. The rich potential of immersive virtual reality is also utilized in areas that use geographical data, for example, evacuation planning [22,23], geospatial data exploration and analysis [24-27], navigation in urban areas [28,29], visualization of spatial data quality [30], and urban planning [31].

Immersive virtual reality is also significantly employed as an educational tool in many areas. We can find its educational application in domains such as engineering [32,33], biology [34,35], foreign languages [36], geometry [37], emergency management [38], physics [39], design [40], geography and earth sciences in general [41-45], and in other more singular domains such as martial arts [46] and communication skills training for individuals with autism [47]. Virtual environments including VR have a long tradition in geographical research and education [48-51], but until recently, user experiences have only been rarely reported. Several recent studies analyzed the potential benefits of immersive technologies for education in geography and task solving. Philips et al. [52] examined the usage of immersive 3D geovisualization and its usefulness in a research-based learning module (flood risk assessment). The findings of a qualitative student survey showed a range of benefits (improved orientation in the study area, higher interactivity with the data, and enhanced motivation through immersive 3D geovisualization) and suggested that an immersive 3D visualization can increase learning effectiveness in higher education. Focusing specifically on hypsography education using modern technology, Carrera et al. [53] studied the possibilities of Augmented Reality technology (AR). They experimented with 63 students and tested the usability of AR to interpret relief (maximum slope, visibility between points, contour interval, and altitude interpretation). Usability was further assessed in terms of efficiency (time to accomplish the task), effectiveness (number of mistakes) and motivation (subjective satisfaction). The results of the study confirmed the enhanced usability of an AR environment for specific tasks dealing with questions of interpreting relief. None of the aforementioned studies combined both VR and a collaborative environment.

Merchant et al. [54] distinguish three types of instruction based on virtual reality technology: simulation, games, and virtual worlds. They conducted a meta-analysis of available empirical studies using desktop-based virtual reality of all three mentioned types of educational approaches. They found that games provided the highest learning outcome gain. They defined the important attributes of educational games, also called serious games [55]. Such games should provide players with sense of autonomy, identity, and interactivity [56] and enable them to test hypotheses, strategize their moves, and solve problems [57].

Collaborative learning is a trend in modern pedagogy for improving the quality of educational outcomes and processes [58-60]. It allows two or more users to interact and solve tasks together-with a critical approach towards the overly ambiguous definitions often used- and may be defined as a situation which Dillenbourg [61] (p. 7) described as "particular forms of interaction among people are expected to occur, which would trigger learning mechanisms." Dillenbourg himself noted that the main concern of learning process designers was to find ways of raising the likelihood that certain types of interaction would occur. What we expected when designing our collaborative immersive virtual environment (CIVE) application was that students would use conversation to continually build, monitor, and repair a joint problem solution, as depicted by Dillenbourg [61]. Collaborative learning principles in college education of technical disciplines were introduced for example by Gokhale [62]. He evaluated the advantages of collaboration in a team of college students and confirmed a positive feedback of collaboration for analysis and synthesis compering to the traditional individual training. Another interesting aspect of collaboration within the VR is a distant cooperation of specialists from 
different disciplines solving complex problems like geohazards (tsunamis, landslides, and floods) [63, 64]. Collaborative learning principles applied in college education for technical disciplines were introduced, for example, by Gokhale [62]. He evaluated the advantages of collaboration in a team of college students and confirmed the positive feedback of collaboration for analysis and synthesis compared to traditional individual training. Another interesting aspect of collaboration in VR is the remote cooperation of specialists from other disciplines engaged in solving complex problems such as geohazards (tsunamis, landslides, and floods) [63,64].

Computer-supported collaborative learning was introduced in the early 1980s as an overarching framework for various attempts to design a "technologically sophisticated collaborative learning environment designed according to cognitive principles" that "could provide advanced support for a distributed process of inquiry, facilitate advancement of a learning community's knowledge as well as transform participants' epistemic states through a socially distributed process of inquiry" [65] (p. 4). Jackson and Fagan [66] conducted a qualitative study where learning processes were explored by comparing individual users, two peer users, and student-expert modes. They used an immersive virtual environment called Global Change World, which is used to educate about concepts concerning global climate change. Other instances of collaborative learning using immersive virtual reality can be found in, for example, the domain of martial arts [67], geometry education [68], and training power system operators [69]. Innovative technologies for collaborative immersive virtual reality may be able to create a shift in the educational paradigm. Siemens [70] has challenged the traditional learning theories through his "connectivism" conception and emphasized that people in the digital age are no longer isolated individuals but located in a network where they continuously interact with human and nonhuman systems. Learning should be considered a lifelong net-building activity. Horvath [71] presents a technological solution in the form of a learning environment enabling collaboration in $3 \mathrm{D}$ virtual reality to teach the concept of the memristor.

The main advantage of using immersive virtual reality for educational purposes is overcoming the boundaries of a specific place and time and having a virtual experimental space [72]. This offers possibilities which are barely achievable or not possible to build in a classic classroom. Our geography learning CIVE application offers a high level of interactivity for the user, which was achieved through iterative testing and development. We also intentionally used gamification principles when creating instructional tasks in order to facilitate the learning process. Our solution incorporates immersive virtual reality, real-time social collaboration, and gamification principles. We chose hypsography as an educational topic, as it is one of the most insufficiently understood areas by our university students (according to the results of the Faculty of Science entrance exams: error rate was 86\% in 2016 and $73 \%$ in 2017). The objective of this study was to describe the cognitive and social tendencies of participants during collaboration on geography learning tasks by applying the interpretative phenomenological analysis methodology.

\section{Methods}

\subsection{Materials and Technology}

This study utilized a geography education CIVE application developed by our interdisciplinary team. It makes use of the Unity cross-platform game engine version 2017.3, which facilitates data loading, real-time rendering, and communication with VR equipment. The CIVE application was built in a virtual environment described by Doležal, Chmelík \& Liarokapis [73]. It is used in combination with SteamVR for the proper functionality of VR equipment. Authentic geospatial data were implemented as stimuli in the application. Digital terrain models (DTMs) were used as the main input data. A fifth-generation digital terrain model (DTM 5G) created by airborne laser scanning was acquired from the Czech Office for Surveying, Mapping and Cadastre. DTMs in the application represent various parts of the Czech Republic with a similar relief. Data were transformed by doubling the vertical values to accentuate the relatively small variation in landscape altitude. DTMs 
were supplemented by contour lines also generated from the DTM data as well as orthophoto images provided from a WMS (Web Map Service).

The application creates a shared virtual room for multiple users. Even though users are physically located in separate objective reality rooms, the VR headset lets them share a virtual room to collaborate on a given task. Physical movements in the objective reality room are tracked and transferred to the virtual room, which means users can walk around the room and examine geospatial material from all sides, angles and distances. In the virtual room, each participant is displayed as an avatar with virtual representations of controllers he or she is holding in objective reality (Figure 1). Controllers are used to manipulate the virtual environment and provide a laser pointer for communication. Users can also talk to each other via standard audio recording and reproduction devices. Objects added to the scene, such as houses and dams, are visualized abstractly and simply. It is considered a suitable method for highlighting task relevant objects [74].

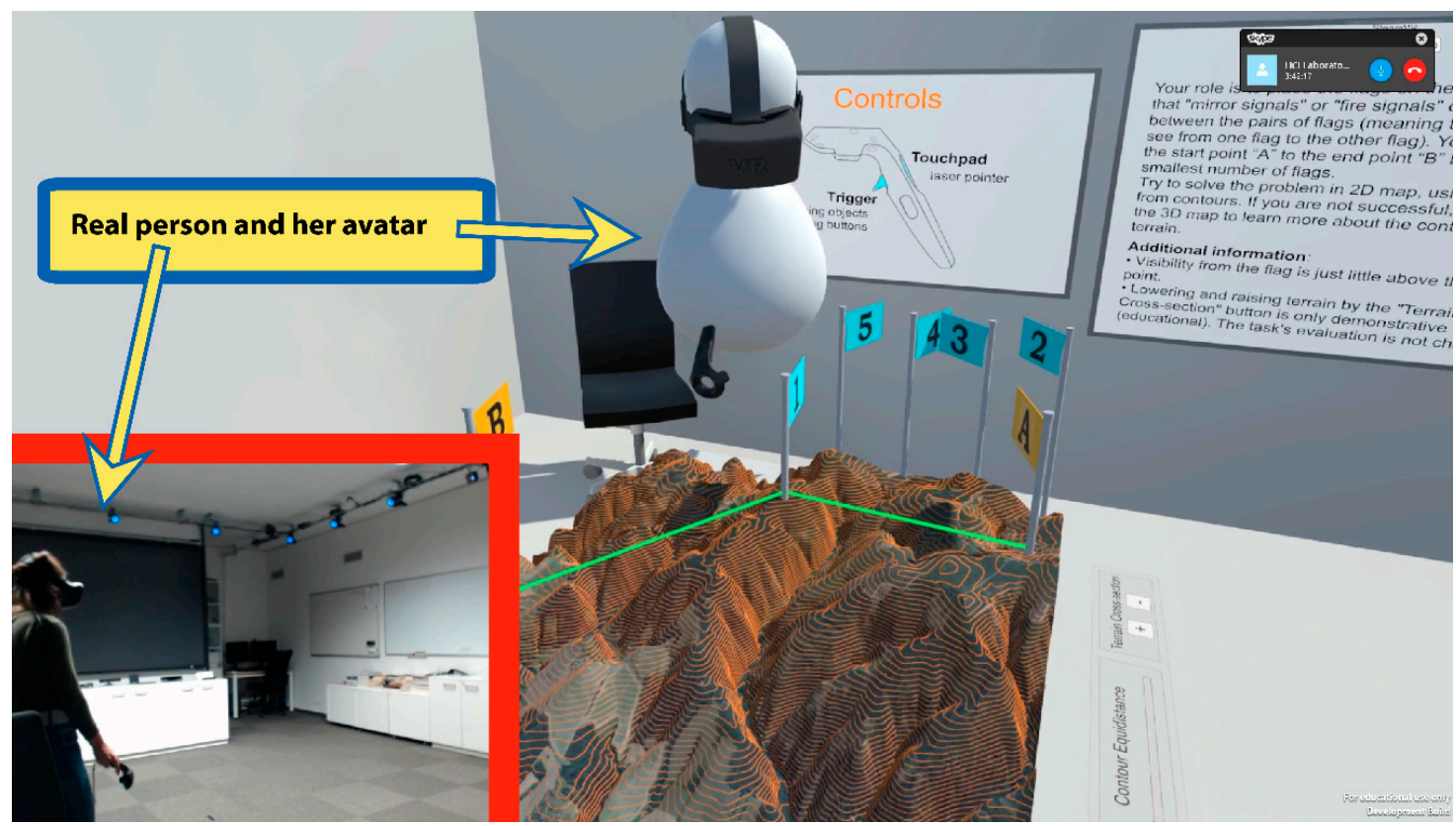

Figure 1. Objective reality (left corner) and virtual room.

The application includes two geospatial tasks. For each task, a different workplace in the room is offered. The room has a table with a map for the first task and a large map on the floor for the second task. Both geospatial tasks in the application require the user to examine contour lines on a 2D map to determine the shape of the terrain in order to find the correct solution.

The default visualization in both tasks is a 2D map. If the user cannot solve the task correctly on a $2 \mathrm{D}$ map, they can use various educational tools to help examine and manipulate the map. The application provides a virtual control panel (Figure 2) next to the map in the CIVE. One of the main advantages is the possibility to switch the map from 2D to 3D at any time. The map can also be switched between a white contour map and an orthophoto contour map. Contour line equidistance can be customized using a slider. Finally, when the user wants to verify their solution, they can use the Evaluate button. 


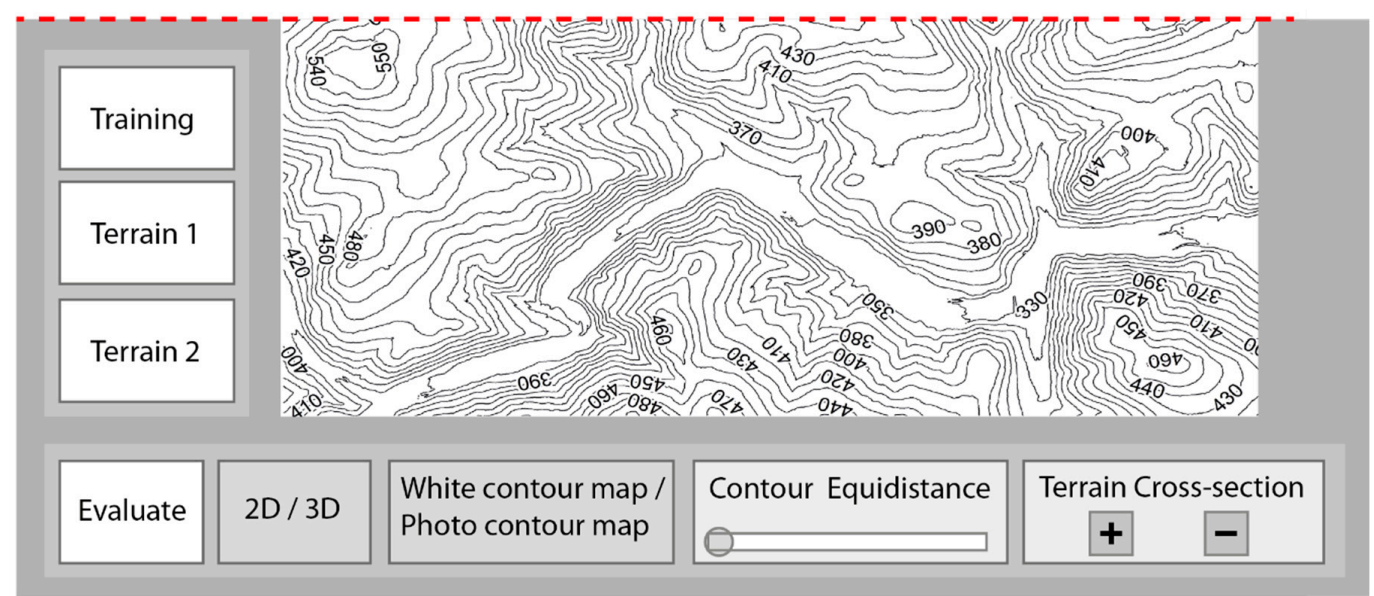

Figure 2. Virtual control panel for model manipulation.

\subsection{Instructional Tasks in a CIVE Environment}

For purposes of this research, two tasks were designed: Task 1-Mirror Signals and Task 2-Flooded Valley. In case of the Mirror Signals task, a map was presented to participants, with two fixed flags marking the start point (flag A) and the end point (flag B). Next to the map were five more available flags numbered 1, 2, 3, 4, and 5, which could be picked up and placed onto the map (see Figure 3). The task was to connect start point A with end point B using these additional flags in a way that mirror signals (or fire signals) could be transmitted between neighboring flags only with direct visibility. This means that the view to flag 1 from flag A, flag 2 from flag 1 , and so on had to be unobstructed until an unobstructed view to flag B was obtained. The goal was to use the least number of flags possible to link the start point with the end point (see Supplement for Video S1). In the first task, the 3D model of the terrain can be dissected into individual layers and a cross-section of the terrain can be viewed.
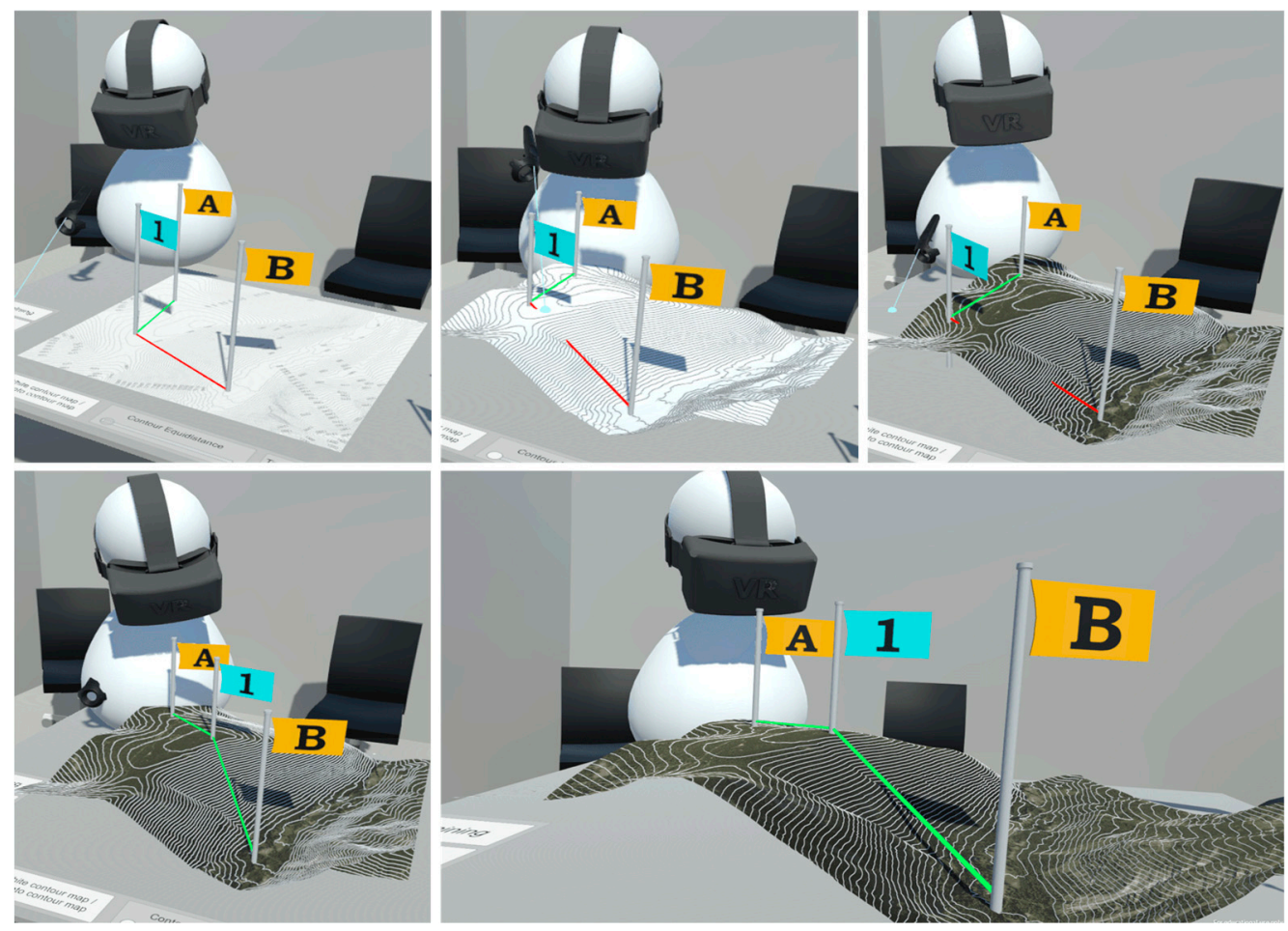

Figure 3. Incorrect (upper) and correct (lower) answers for the mirror signals task in the collaborative immersive virtual environment (CIVE). 
As in Task 2-Flooded Valley, a 2D map was presented to the participants that included houses (orange rectangles) in a recognizable valley surrounded by mountain ranges and a dam (red line) (Figure 4). Just as in the previous task, five flags numbered 1, 2, 3, 4, and 5 were next to the map and could be picked up and placed onto the map. The scenario and task were as follows. A new dam has been built to transform a valley with houses into a water reservoir. The water in the valley will gradually rise and flood the houses one by one. Use flags with numbers to mark the order in which the houses will be flooded. After submitting the solution, the participants could watch the rising water gradually flood the houses (see Supplement for Video S2). The water level can be manipulated by user too, which lets the user gradually flood the terrain to see water flooding one contour line after another.
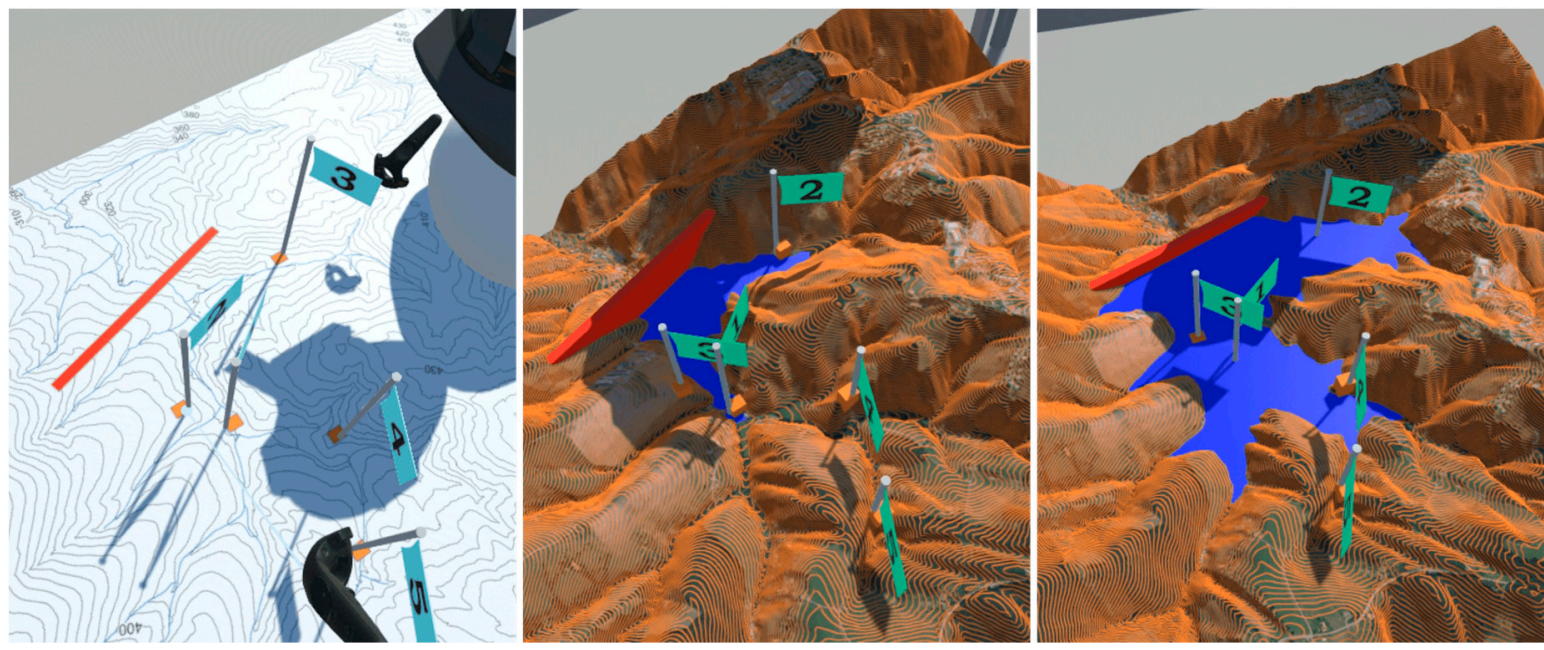

Figure 4. Flooded valley educational task in the CIVE. Left-flags with numbers are placed onto the 2D contour line map, middle-water level starts rising in the 3D visualization, and right-3D visualized dam is completely flooded.

\subsection{Research Approach}

To examine the user experience in our geography learning CIVE application, an experiential qualitative approach of Interpretative Phenomenological Analysis (IPA) was applied. This approach explores the lived experience of a person and the meaning he or she attributes to it while exposed to a specific phenomenon, for example, a short-term event or a long-term process. Its aim is to create an in-depth description of a person's lived experience during exposure to a particular phenomenon.

IPA is a frequently used strategy for research topics in weakly examined areas where the background theory has not yet been sufficiently developed. It is flexible in dealing with unexpected data that occur during research. It is therefore an ideal tool for gaining insight into and understanding the innovative use of a CIVE for geography learning or learning in general [75]. A research question in IPA is open, and although IPA is not a theory-driven approach, literature usually contributes to formulating a research question [76], as was also the case in our study. IPA does not test hypotheses and attempts to avoid creating preconditions before research. It is an inductive approach which is rather "bottom-up" than "top-down" [77].

The number of participants in IPA research depends on the richness and saturation of individual cases. Participants are experts on their own experiences and can offer the researcher an understanding of their ideas, associations, and feelings. The recommended upper limit of participants is ten [78]. Creating a research sample is based on purposive sampling and participants are selected according to relevance criteria for the research question.

Data collection in our IPA study implemented triangulation $[79,80]$ from three research techniques (Figure 5). Using three different and complementary research techniques for data collection makes 
it possible to harvest the strongest aspects of all the techniques and mutually compensate their weak spots.

\section{Focus group}

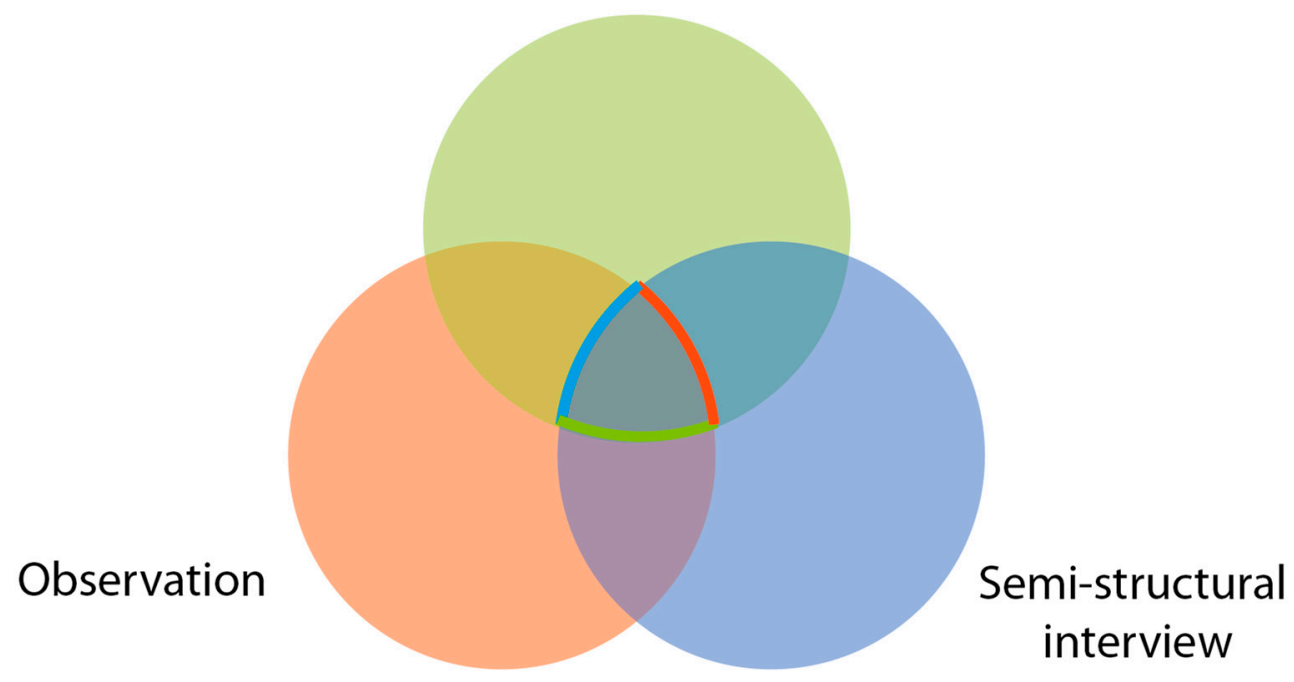

Figure 5. Triangulation of research techniques for data collection.

Half of the participants involved in the study were interviewed in pairs in a semistructured interview. The researcher sets up the key topics before interviewing, such as learning experience, gained understanding of the learning topic, and means and effectiveness of communication with a collaborator. The advantage of an individual or dyadic interview is a controlled, detailed, and deep exploration of an individual's unique experience. The other half of participants was interviewed in a focus group. As a research technique, the focus group minimizes the influence of the researcher and any preconceptions which could direct or distort the participants' statements. The researcher moderates a discussion and gives participants free space to share their individual experiences. However, some important topics can be omitted by participants, which is the most significant disadvantage of the focus group technique and the reason for our choice to use semistructured interviews to compensate for this potential weakness. Nevertheless, the key advantage of both techniques mentioned is that they bring new topics to light.

Subjectivity of the acquired data also poses a challenge. To overcome the potential risk of low validity, we conducted observations. All participants were observed and video recorded during their experience of the CIVE. We monitored voice communication, movement in objective reality and the avatars in virtual reality as tasks were completed. This data provides researchers not only with objective complementary information to the subjective reports, but also captures reactions and behavior performed unconsciously by the participants.

\subsection{Research Environment and Equipment}

The study took place at Masaryk University in Brno, Czech Republic, in two separate rooms. Each room was equipped with a computer (Intel ${ }^{\circledR}$ Core $^{\mathrm{TM}}$ i5-6500 processor, Nvidia GeForce GTX 1080 graphics card, 16 GB RAM) connected to an HTC Vive headset $(1080 \times 1200$ px resolution for each eye, $90 \mathrm{~Hz}$ refresh rate), sensors, and a controller. A participant and a researcher were present in each room. The rooms offered enough space for participants to move around and were sound insulated from the outside environment. 


\subsection{Participants}

To design and structure the interview questions, one pair of participants was interviewed in the preparation phase. It was an in-depth phenomenological interview with a pair of "experienced" VR users conducted after collaboration in the CIVE application. Researchers themselves were involved as preparation phase participants to gain personal experience with the CIVE and educational tasks. The initial analysis resulted in a few changes to the research procedure, task setup, and virtual control panel being made. The interview with preparation phase participants also focused on their overall experience in the CIVE. Based on the information acquired, a semistructured interview schedule was created for interviewing research participants.

Research participants were recruited from the pool of volunteer students and academic teachers from the Faculty of Arts. Two exclusion criteria were applied. The first exclusion criterion was previous formal training in cartography. The second exclusion criterion was the occurrence of cybersickness in previous experiences with virtual reality or during this study. Participants were asked to report any cybersickness and were briefed on options to end participation at any moment if required.

The final research sample consisted of 12 participants who collaborated on geospatial tasks in the CIVE application in pairs. The pairs were established randomly. Seven participants were women and five were men. The mean age of the participants was 27.58 years, the minimum age was 22 , and the maximum was 43 . None of the participants had undergone specific GIS user training and none were significantly experienced VR users (including, for example, VR gaming).

\subsection{Procedure}

Participants who volunteered to this study underwent a procedure consisting of five steps: 1 . Informed consent and collection of demographic data; 2. VR manipulation training; 3 . Research procedure instruction and contour lines principle explanation; 4. Collaboration in the CIVE (Figure 6); and 5. Inquiry. With a pair of participants, the procedure varied from one to two hours.

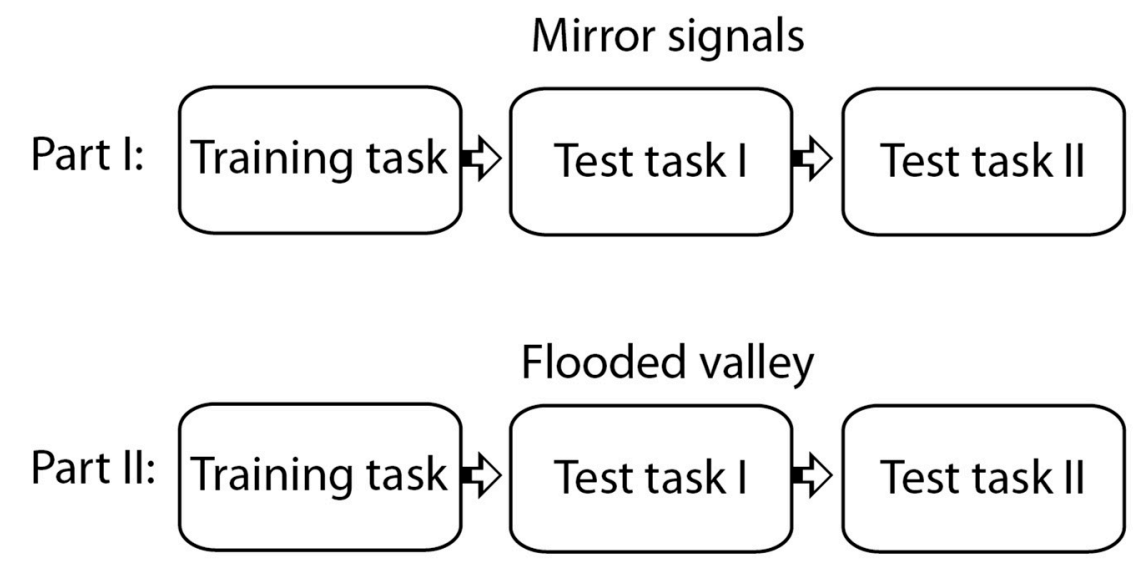

Figure 6. Step 4: collaboration in the CIVE-research tasks administration in detail.

\subsection{Analysis}

We employed specific idiographic case study data analysis in the IPA and the variation for multiple cases (respectively, multiple participants) as described in Smith et al. [78,81,82]. This analysis focused mainly on the shared experience (common characteristics of experience) of participants, but also mentioned significant and distinct experiences [77]. An analysis is slowly built-up by reading individual cases and creating statements about the whole group of participants. The analytic process is cyclic (iterative). The themes are reconsidered and rebuilt many times [78]. The results are transparent because they are evidenced by data examples (quotations). The results are structured according to theme. As shown in Figure 7, the analytic process cycle is as follows. 


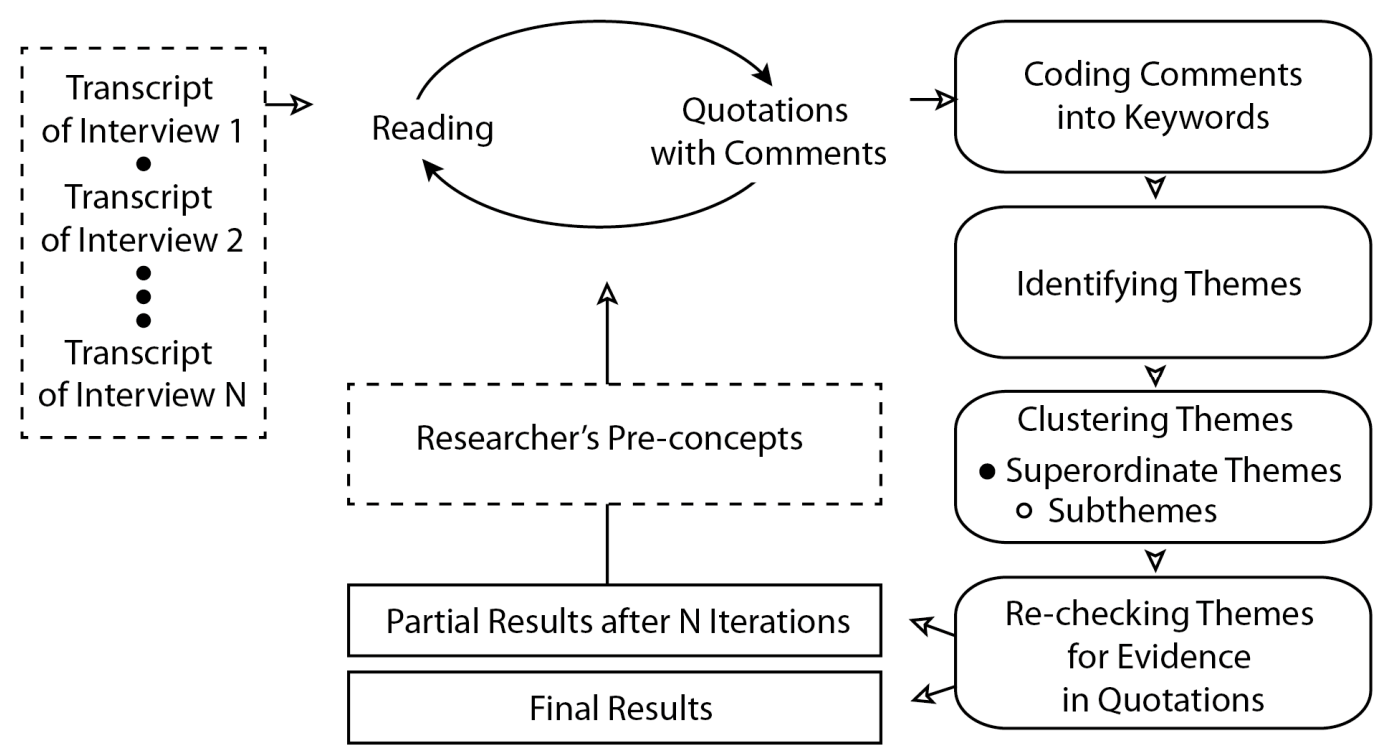

Figure 7. Scheme of the interpretative phenomenological analysis.

After transcribing the first interview, its content was read by a researcher repeatedly and significant quotations were marked and annotated (comments included preliminary interpretations and ideas from the researchers). This phase was repeated several times and the comments were then coded into keywords from which important themes were identified. These themes were then structured into a list of superordinate themes and subordinate themes belonging to each superordinate theme. Next, the themes were rechecked for evidence in verbatim excerpts (participant quotations), after which the analysis could proceed to another participant using the preliminary concepts gained from the previous interview as a framework for analysis of the next interview (Figure 7). Each participant's interview analysis was thus thoroughly considered when the next interview was analyzed, and the final list of themes applying to all participants (as described below) was based on in-depth analysis of all interviews.

\section{Results}

Four superordinate themes emerged from the analysis. Under these superordinate themes, several subthemes were identified, all of which are introduced in detail in the text below. The themes are well illustrated by verbatim excerpts from the data corpus, which are included in the tables. The main structure follows the most relevant topics: collaboration, learning, map literacy, communication, and cognition.

\subsection{Appreciation for Having a Collaborator}

The first superordinate theme relates to the thoughts and feelings of the participants towards their collaborative partners and is characterized by the appreciation of having a collaborator to solve the tasks. The collaborator motivated them and provided the opportunity to consult on the solution.

This superordinate theme includes two subthemes which we called 'Lost without a collaborator' and 'Verification and consensus with a collaborator' and are also described below.

\subsubsection{Lost without a Collaborator}

A key aspect prevalent throughout the accounts of collaboration was that the participants would have felt lost without a collaborator. They expressed doubt as to whether they would be able to solve the task individually. Collaboration helped them solve the tasks. They were very happy they could talk to their collaborator. Participants talked a lot, which made it easier for them to understand the task. They believed that they would have been staring at the task for a long time if they had not been 
working with a collaborator and would have felt uncertain and stagnated. Participants estimated that a collaborative solution was more effective than solving the task individually and did not believe that independent work on this task would have had any benefit (Table 1).

Table 1. Verbatim excerpts of statements by participants: Lost without a collaborator.

\begin{tabular}{|c|c|}
\hline P13 & $\begin{array}{l}\text { "I wouldn't have managed it myself, so, like, I don't even have experience with it, so I was } \\
\text { really glad that there was someone with me who would say to me: 'Yeah, this ...' '" }\end{array}$ \\
\hline P14 & $\begin{array}{l}\text { "I was quite pleased to hear the other person's opinion. If I had done it like alone, it might } \\
\text { have been a bit sad ( ... ) would've had to think about whether it was correct, whether I'd } \\
\text { made the right decision. But this way, when I had you and you helped me with it ..." }\end{array}$ \\
\hline \multirow[b]{2}{*}{ P09 } & $\begin{array}{l}\text { "We were looking at it together and solved it together, because we talked a lot the whole } \\
\text { time, so ... it seemed more, like, understandable to me." }\end{array}$ \\
\hline & $\begin{array}{l}\text { "It helped me a lot to have a collaborator, because I would have stared at it for a very long } \\
\text { time and would have been very uncertain, because I was wandering a little in it, so it } \\
\text { helped me a lot when the collaborator said: 'Let's just solve it in one minute and go to the } \\
\text { next one' ... and that was just great, because we just needed to try it and we tried it." }\end{array}$ \\
\hline \multirow[b]{2}{*}{ P12 } & $\begin{array}{l}\text { "This way, it was even more fun and faster." "This interaction is always as if time always } \\
\text { flies faster. If I had been there alone, I would have looked around more." }\end{array}$ \\
\hline & $\begin{array}{l}\text { "If I had been there alone, I would've looked half an hour somewhere else where } \\
\text { something else was, but because there were two of us, I focused more on the task, because } \\
\text { you always pulled me back to it." }\end{array}$ \\
\hline
\end{tabular}

\subsubsection{Verification and Consensus with the Collaborator}

Participants described that as they made decisions about solutions to the task, they usually consulted their collaborator to verify the answer before submitting it. They sought consensus on the right solution together. Participants discussed their viewpoints and the specifics of a particular task which could influence the answer. They talked to the collaborator about which strategy or key they should use to solve the task. The usual modus operandi among the pairs of participants was to talk about a strategy for the solution, reach an agreement on the correct answer and then submit it. They were therefore much more confident when submitting the answer and felt better about it. It also helped them to inspire each other. When anyone in the dyad discovered a useful strategy, they shared it and both then used it. Solving the task with a collaborator was reported as more effective. Participants usually discussed and decided on a solution together (Table 2).

Table 2. Verbatim excerpts of statements by participants: Verification and consensus with the collaborator.

\begin{tabular}{|c|c|}
\hline P04 & $\begin{array}{l}\text { "I consider collaboration as good, because it verifies that I thought about something. I asked the } \\
\text { collaborator whether he saw it the same way, and he said that he did, and in that case we } \\
\text { submitted it." }\end{array}$ \\
\hline P03 & $\begin{array}{l}\text { "We just agreed on how to do it." "It seemed to me as less ambiguous and so we found some... } \\
\text { consensus about the right solution, and whether we saw something special about that case." }\end{array}$ \\
\hline P09 & $\begin{array}{l}\text { "We discussed the task, searched the key which we would establish as a solving strategy, and } \\
\text { using laser pointers, showed each other the things we were currently talking about." }\end{array}$ \\
\hline \multirow[b]{2}{*}{ P11 } & "We always talked nicely about it, to both agree on it before we completely submitted it." \\
\hline & $\begin{array}{l}\text { "If the collaborator was thinking the same thing I was, then it was easier to submit the answer, } \\
\text { but individually I would maybe have thought about it more or ... but I think it also helped me } \\
\text { to understand it, because both of us found something relevant and then we both used it further, } \\
\text { so we were enriching each other." }\end{array}$ \\
\hline P12 & $\begin{array}{l}\text { "I think that thanks to the fact that we evaluated it little by little, the process was more efficient } \\
\text { than it would have been if I had been there alone, then I would either think about it more or } \\
\text { have made more mistakes." }\end{array}$ \\
\hline
\end{tabular}




\subsection{The Surprising "Fun with Maps"}

The second superordinate theme relates to the reported level of excitement the participants felt while working on geospatial tasks in the CIVE application, although most participants verbalized that they usually did not enjoy working with maps and considered them boring. Moreover, working in CIVE also enhanced the educational effect.

This superordinate theme includes the two subthemes. Finally, seeing what contour lines represent in reality and learning a skill to work with maps.

\subsubsection{Finally Seeing What Contour Lines Represent in Reality}

Many participants explained that thanks to being able to switch the 2D map to the 3D model of the terrain, which they could examine and walk around freely, an association developed in their minds between what a contour line looked like on paper and what it represented. Virtual reality helped them solve the task and see the correct answer more clearly. They found it helpful to use educational tools for visualization in 3D, for example, raising the terrain's water level to see how contour lines were flooded one by one. All of this helped them learn about contour lines and create associations between 2D maps and real 3D terrain (Table 3).

Table 3. Verbatim excerpts of statements by participants: Finally seeing what contour lines represent in reality.

\begin{tabular}{|c|c|}
\hline P03 & $\begin{array}{l}\text { "On one hand it was great, because now you know where the contours are and what they } \\
\text { look like and stuff, and then the virtual reality is turned on and then it (the 3D model) } \\
\text { emerged, which I think is great." }\end{array}$ \\
\hline P09 & $\begin{array}{l}\text { "It really was helpful and I could see it in that more clearly... It was like it allowed me to } \\
\text { concentrate really well on the task." }\end{array}$ \\
\hline P12 & $\begin{array}{l}\text { "And I think it really helped us to gain insight, so in the next task our imagination was } \\
\text { better, that we could imagine it better, and that what we created is some model of how } \\
\text { those contours look like in reality." }\end{array}$ \\
\hline P11 & $\begin{array}{l}\text { "Yes, I think it helped even in understanding what contours actually are, when the person } \\
\text { then really sees it as the real differences in height, that it's not just lines." }\end{array}$ \\
\hline \multirow{3}{*}{ P14 } & "In fact, normally a person can't see it like this, as in that virtual reality." \\
\hline & $\begin{array}{l}\text { "With that flooding, certainly, like flooding, imagining that water, as it rises. When we } \\
\text { evaluated it, it was then easier to shift it and see how the water would rise than if I had to } \\
\text { imagine it on the table." }\end{array}$ \\
\hline & $\begin{array}{l}\text { "In fact, this can be utilized in many ways, even, like, only in education when a person } \\
\text { imagines how it looks in reality. So this was great." }\end{array}$ \\
\hline
\end{tabular}

\subsubsection{Learning a Skill to Work with Maps}

An additional and clearly identifiable subtheme which emerged from the analysis relates to the new skill participants learned for working with maps. Participants explained that they had acquired a better understanding of contour lines and that if they came across similar tasks in the future, they would be able to solve it faster. Our educational application was seen as a good learning and training tool for improving map orientation skill and decreasing the time it occupied. For some participants, maps were an alien territory, but with our CIVE application, their map orientation skills improved. Their map reading speed increased and it was now easier for them to imagine terrain (Table 4). 
Table 4. Verbatim excerpts of statements by participants: Learning a skill to work with maps.

\begin{tabular}{|c|c|}
\hline P04 & $\begin{array}{l}\text { (if they had to solve a similar task in the future) "Well, certainly it would be better. On that } \\
\text { level, we wouldn't be looking at it for five minutes and ... (participant laughs) ... and } \\
\text { wouldn't be trying to understand contours." }\end{array}$ \\
\hline P11 & $\begin{array}{l}\text { (if they had to solve a similar task in the future) "Like, I would probably be pretty much } \\
\text { orientated in it ... such good training." }\end{array}$ \\
\hline P03 & $\begin{array}{l}\text { "We learned to read contours much better, perceive them and search for them even in that } \\
\text { not completely biblical environment, because neither of us is a geographer and we weren't } \\
\text { used to using contours every day, and that ability to orientate gradually improved." }\end{array}$ \\
\hline \multirow[t]{2}{*}{ P04 } & $\begin{array}{l}\text { "We are certainly a little, or at least I am, someone who doesn't work very often with } \\
\text { contours. I have oriented myself in that environment, so now I'm on ... now it would take } \\
\text { me less time to recognize, where the hills and valleys are." }\end{array}$ \\
\hline & $\begin{array}{l}\text { "I actually didn't see that terrain at all, so I think that actually for a long time both of us only } \\
\text { looked at it." "Later we were faster reading the map." }\end{array}$ \\
\hline P13 & "Much better, I can imagine it better as, like ... now I can imagine it better." \\
\hline
\end{tabular}

\subsection{Communication as a Challenge}

The third superordinate theme relates to the effort participants made to communicate their thoughts and feelings to the collaborator. Participants described that they had to concentrate more on facilitating communication by the means they had available in the virtual environment.

It includes three subthemes: Absence of avatar faces and invisibility of emotions, limited gestures via controllers, and having an intangible body.

\subsubsection{Absence of Avatar Faces and Invisibility of Emotions}

Many participants felt they had limited options when it came to communicating emotions to their collaborator. One of the first things they noticed was that avatars had no faces. Some of the participants looked at their collaborator's avatar when they talked to them, and some did not. Most of the participants considered faces as important and missed them in the virtual reality environment for conveying emotion. Besides, participants considered it important to see where their collaborator was looking. This was possible in our CIVE application, but they were not surprised at being unable to look their collaborator in the eyes, as they had expected it this way. Some of the participants wondered whether it would be strange or disturbing if their collaborator's avatar had some representation of a face, as there could be discrepancies between what the person was trying to communicate and the emotions the artificial face managed to convey (Table 5).

Table 5. Verbatim excerpts of statements by participants: Absence of avatar faces and invisibility of emotions.

\begin{tabular}{|c|c|}
\hline P10 & $\begin{array}{l}\text { (collaborator having no face) "It seemed terribly comic to me, like, when we talked to each } \\
\text { other-that alone made me laugh for a long time." }\end{array}$ \\
\hline P12 & $\begin{array}{l}\text { "Yes, I had to adjust my ways a little in communicating, for example, gestures and ... } \\
\text { Basically, we didn't even see each other's facial expressions, and facial expressions are also } \\
\text { quite important, so I didn't see what facial expressions she had ... when I heard her } \\
\text { laughing, I heard that, but when you can't see the other person's eyes, it's that different." }\end{array}$ \\
\hline P04 & $\begin{array}{l}\text { "Sometimes I missed those, like, emotions there, that I was, like, smiling (participant laughs) } \\
\text {... and there was no way of passing it over and then I always realized that I'm smiling in an } \\
\text { empty room." }\end{array}$ \\
\hline P03 & $\begin{array}{l}\text { "I considered it important to be able to see where that person was looking or what he was } \\
\text { calculating or something." }\end{array}$ \\
\hline P06 & $\begin{array}{l}\text { (collaborator having no face) "I probably expected it. I've seen it before." "Natural, it } \\
\text { probably wasn't ... (participant laughs) ... but it was probably not surprising." }\end{array}$ \\
\hline
\end{tabular}


Table 5. Cont.

\begin{tabular}{|c|c|}
\hline P10 & $\begin{array}{l}\text { "I wonder if it would have been stranger if it had simulated a person even more and then } \\
\text { there was some discrepancy, even like, that it would have had a more realistic face, then it } \\
\text { might have been even stranger." }\end{array}$ \\
\hline P08 & $\begin{array}{l}\text { "There should rather be a square than a simulation of the shape of a head, or that, as you } \\
\text { said, being deformed, that is probably not what a person really wants, for it to resemble } \\
\text { a person." }\end{array}$ \\
\hline P10 & $\begin{array}{l}\text { "Maybe it also then even evokes some emotions, and that is probably not what is intended, } \\
\text { for people to act according to it." }\end{array}$ \\
\hline
\end{tabular}

\subsubsection{Limited Gestures via Controllers}

When participants were asked to describe their experience of communicating with their collaborator, they often described the need to modify their communications and actions because they had avatars instead of real bodies. Participants mentioned that the collaborator's representation was fine, but if the avatar had been more detailed, it would have been even better, as they wanted to see their collaborator's gestures. They would then look at their collaborator during communication more often. However participants say it was possible to read information from the posture and proximity of the collaborator's avatar. They had to think about how to depict something during communication when the collaborator could not see them fully. It was apparently demanding, but also fun. It required an unusual style of thinking which required the participants to consider the selection of gestures. They managed, however, to adapt to the visible parts of their avatar and used only those to communicate (Table 6).

Table 6. Verbatim excerpts of statements by participants: Limited gestures via controllers.

\begin{tabular}{cl}
\hline P04 & $\begin{array}{l}\text { "To me it seemed okay, but certainly if that avatar functioned better and I could even look at } \\
\text { gestures, then it would be better. That probably ... like I would use more, I would try to } \\
\text { communicate more and I would even look at him more." }\end{array}$ \\
\hline P12 "That is true, I actually also gestured with my hands and ... it wasn't actually being seen ... \\
so I had to, like, with that controller." \\
"Sometimes I looked where you were standing, but I couldn't make out a lot from that, and \\
P04 $\begin{array}{l}\text { yeah, I saw for example, that he was currently leaned over the numbers, yeah, and ... } \\
\text { actually yes, when I think about it, you looked, for example, I saw, that he was currently } \\
\text { leaned over the numbers, so I assumed he was currently solving something." }\end{array}$ \\
P12 $\begin{array}{l}\text { "One tries out a little different way of communicating. Maybe he concentrates a little more } \\
\text { on what he's doing with the hands, legs, what and how he moves and how to communicate } \\
\text { something to the other person, so you have to take into consideration what he sees." }\end{array}$ \\
$\begin{array}{l}\text { "Well yeah, well, since it was a little bit more limited with those avatars, as with that, that } \\
\text { there weren't all the details, then it was a little bit more interesting, so ... that sometimes } \\
\text { there's too much detail." "I actually had to think about it, how to show something } \\
\text { considering that I will not be seen as a whole, and, like, when I show something with my } \\
\text { hands, that the hands actually were not seen." }\end{array}$ \\
$\begin{array}{l}\text { "Yeah, I've been able to adjust to what is actually visible and somehow just move only with } \\
\text { those things that are visible." }\end{array}$ \\
\hline "So I think a person gets used to it quickly ... he learns how to work with what he sees." \\
\hline P12
\end{tabular}

\subsubsection{Having an Intangible Body}

All the participants dealt with the fact that their body in VR was not composed of any physical material. The situation when the avatars of both participants stood in the same virtual space or when an avatar stood "inside" a virtual object occurred. The physical area around a participant was always free, and the decision not to walk through virtual objects was always up to the participant. Participants 
tried to keep a usual personal distance between themselves and the collaborator, even though it was only an avatar.

Many participants mentioned the problem of obstructing or shadowing each other's view. When a collaborator stood in the map, it was quite a big problem and hard for the other person to read contour lines, but they did not realize they were doing it. Participants usually did not tell each other. They recognized the problem, but it usually only lasted a few seconds before the collaborator changed position and they could see the map again.

However, participants mostly did not mind that their avatar was not physical. It only bothered them at the beginning on account of habit (Table 7).

Table 7. Verbatim excerpts of statements by participants: Having an intangible body.

\begin{tabular}{|c|c|}
\hline P04 & $\begin{array}{l}\text { "When my collaborator appeared in that first room during the first task, and when you, like, } \\
\text { moved to the flags and I stepped out of your way, right, to like make space for you, so in that } \\
\text { moment I was fully aware of the fact that I actually didn't have to move and that we could } \\
\text { be both there, one through another, but, but I made a step back (participant laughs), because } \\
\text { it seemed a little bit awkward." }\end{array}$ \\
\hline P03 & $\begin{array}{l}\text { "I guess I would make him space, if I could. I would probably respect the personal zone } \\
\text { even in cyberspace." }\end{array}$ \\
\hline P11 & $\begin{array}{l}\text { "When I was looking at something and I was, like, leaned over it, like that I was thinking } \\
\text { about something, and since she didn't see me as a whole, so I thought I wouldn't be } \\
\text { obstructing and then I found out that I'm obstructing there with my whole body, and that } \\
\text { she didn't see the map at all." }\end{array}$ \\
\hline P12 & $\begin{array}{l}\text { "Well, there was such, such a funny thing, when you were standing there somehow through } \\
\text { the table and it wasn't possible to see through it at all and it was so weird." }\end{array}$ \\
\hline \multirow{5}{*}{ P04 } & $\begin{array}{l}\text { "it was quite a big problem, but it didn't occur to me at all that I could be shadowing you, } \\
\text { but because we both got in there, that we both walked inside that map since it was difficult } \\
\text { to read, but then I didn't see those contour numbers or the contour heights actually in that } \\
\text { moment, when the person was standing exactly through the map, that's true." }\end{array}$ \\
\hline & "And we never said to each other: 'hey please make a step back'." \\
\hline & $\begin{array}{l}\text { "I was dealing with it as with a problem, certainly, but probably in the same moment you } \\
\text { walked further on, so it didn't bother me anymore." }\end{array}$ \\
\hline & $\begin{array}{l}\text { "I think it was really a matter of a few seconds." "The fact that the body actually took up } \\
\text { quite a lot of space was not okay." }\end{array}$ \\
\hline & $\begin{array}{l}\text { "I found it good that we could place the flags through each other in there, that you could } \\
\text { place them here and I could place it there and you here and that we could cross over each } \\
\text { other like this." }\end{array}$ \\
\hline
\end{tabular}

\subsection{Cognition in Two Realities}

The fourth and final superordinate theme relates to the cognitive aspects of simultaneously existing in two realities: objective and virtual reality. Participants were present in objective reality but also felt the sense of presence in virtual reality.

This superordinate theme includes three subthemes: Where are my legs? Immersion and involvement in the artificial world and confusion during the return to objective reality.

\subsubsection{Where Are My Legs?}

This question was asked by one of the participants, while other participants also wondered why their avatar looked so rudimentary. Many participants could not adapt to not seeing their own legs. They were strongly conscious of their absence, some even intrigued by it, as they were accustomed to seeing their legs as they looked down. Most participants would have been happier to have virtual legs in the virtual environment. By contrast, one participant did not mind that she had no legs, but did not like that the collaborator was missing legs (Table 8). 
Table 8. Verbatim excerpts of statements by participants: Where are my legs?

\begin{tabular}{|c|c|}
\hline & $\begin{array}{l}\text { "When I put the headset on, I couldn't get used to, like, that I don't have any legs, I don't } \\
\text { have a wristwatch. I was aware of these two things very strongly from self-perception." }\end{array}$ \\
\hline P03 & $\begin{array}{l}\text { "I found it interesting not to actually see the legs. Because always when I put my glasses on } \\
\text { and look, when a person looks down and he is walking somewhere, then he can see his legs } \\
\text { and now I didn't see them, so that was interesting to me." }\end{array}$ \\
\hline P08 & $\begin{array}{l}\text { "It wasn't very pleasant when I looked down, then I felt that I just have them (legs), but } \\
\text { they're simply not there." }\end{array}$ \\
\hline P11 & $\begin{array}{l}\text { "It was quite odd that I was actually in the table, or, like (participant laughs) ... moving, not } \\
\text { actually seeing my own legs, knowing that the legs are probably right where the table was } \\
\text { (participant laughs) ... kind of a strange feeling." }\end{array}$ \\
\hline P09 & $\begin{array}{l}\text { "Maybe just because I didn't see the legs in there, then I didn't mind going through the } \\
\text { table." }\end{array}$ \\
\hline P11 & $\begin{array}{l}\text { "I was quite glad that if the legs had been displayed in there and I saw them go through the } \\
\text { table, then it might have been even stranger." }\end{array}$ \\
\hline
\end{tabular}

\subsubsection{Immersion and Involvement in the Artificial World}

The experience of being in immersive VR was characterized by the loss of tracking objective reality and having a stronger sense of presence in the virtual environment. Immersed in VR and wholly engaged in the task, participants felt a stronger sense of presence in virtual reality. They did not perceive or think about what may have been happening around them in objective reality. While in VR, they had no need to be in touch with the outside world. Only when they bumped into something or heard the experimenter speak did they think about where someone or something was and feel disoriented (Table 9).

Table 9. Verbatim excerpts of statements by participants: Immersion and involvement in the artificial world.

\begin{tabular}{cl}
\hline P09 & $\begin{array}{l}\text { "On one hand, I was really, like, immersed in that task and in that activity, and on the other } \\
\text { hand . . so it was really, like, absorbing for me." }\end{array}$ \\
\hline P13 $\begin{array}{l}\text { "Well, I just bumped into something there, but otherwise I had no clue who was doing what in } \\
\text { here." (in the objective reality room) }\end{array}$ \\
P11 "I was actually more in that virtual reality than in the real reality, actually. Sometimes I really \\
didn't perceive the real reality, I put myself into it a lot."
\end{tabular}

\subsubsection{Confusion during the Return to Objective Reality}

All of the participants liked the virtual environment and became accustomed to it, and most did not want to leave it. Although most of the participants described that they did not have any problems after taking their headsets off, some described specific feelings and perceptions which they experienced for a short time after they had returned from VR to objective reality. 
For instance, one participant described how shocked he felt seeing his real hands again after leaving VR. A moment after leaving VR he felt lightweight and thought he would faint and felt strange even after some time. The time after exiting VR was more disorienting to him than the time spent in VR.

As mentioned above, though, most participants described no awkward feelings after taking their headsets off. They did not need to adapt to objective reality; it was completely normal for them to return to the objective reality room (Table 10).

Table 10. Verbatim excerpts of statements by participants: Confusion during the return to objective reality.

\begin{tabular}{|c|c|}
\hline \multirow[t]{3}{*}{ P08 } & $\begin{array}{l}\text { "For me it was a shock to see my hands again after I took the headset off, and I had a clear } \\
\text { feeling that when I was standing in that other room, I could simply walk through the person in } \\
\text { there, that my hand could just pass through that person." }\end{array}$ \\
\hline & "It's still strange. For a moment after sitting down, I felt as if I'd pass out." \\
\hline & $\begin{array}{l}\text { "So that one feels lightweight and just feels as if the wall isn't there, that I could walk through } \\
\text { it. For me, it was probably a much more shocking experience after than with the headset on. } \\
\text { And I wondered how I would feel if I layed down now, because I actually didn't even see my } \\
\text { hands, I perceived it as those hands when I looked, like: "Wow" and I would probably, I } \\
\text { would certainly not want to willingly go out of the room and go, for example, out onto the } \\
\text { street, because I would be afraid that I, like, can't control it and that something could happen." }\end{array}$ \\
\hline \multirow{4}{*}{ P11 } & $\begin{array}{l}\text { "Yeah, I liked it there, that I didn't want to come back, but then when I took the headset off, } \\
\text { then it was actually ... quite strange, that it was, like, drawn, the real things. So I had to } \\
\text { acclimatize a little bit." }\end{array}$ \\
\hline & $\begin{array}{l}\text { "It seemed to me that things were a little bit smaller, or as the details displayed there, like in } \\
\text { reality, those details are displayed normally, so it was, like, more detailed." }\end{array}$ \\
\hline & $\begin{array}{l}\text { "Then I had problems with reality, that it's, like, too detailed and that I, like, can't perceive it. } \\
\text { Because in the virtual reality I could perceive everything, because it was simpler, so there were, } \\
\text { like, simple stimuli, but in the genuine reality a person has to distinguish what he actually } \\
\text { perceives, because there's a lot of it, so that he can no longer see it as an overall picture with all } \\
\text { the things that are actually there. It's, like, more understandable in there." }\end{array}$ \\
\hline & $\begin{array}{l}\text { "Yeah, yeah, a little bit yes, just only on those details, that I had to perceive reality again, as to } \\
\text { distinguish what I would actually look at, as I already said. Well, but it was just for a moment } \\
\ldots \text { in about three minutes I was okay again. But it wasn't even unpleasant, so it's stupid to say } \\
\text { 'okay', but simply, that I wasn't even perceiving it anymore after I adapted." }\end{array}$ \\
\hline $\mathrm{P} 12$ & $\begin{array}{l}\text { "I didn't want to go back, I liked it there very much. It was, like, when I took the headset off, it } \\
\text { was like, like at first unpleasant, until the eyes got used to it, that I was used to that virtual } \\
\text { reality and to that light and to how it looked there, and then I took the headset off and it was, } \\
\text { like, "Ouuu", a little bit unpleasant." }\end{array}$ \\
\hline
\end{tabular}

\section{Discussion}

In this section, we discuss the results of our study in the context of referenced literature and challenge it with our preliminary expectations and recommend further research and applicational options. The results are already interpretative and deeply descriptive, therefore the discussion to each subtheme will be concise.

One of the main findings of this study was that participants would have felt lost without a collaborator and that working in a dyad brought more entertainment and better results. From a social psychological perspective on collaborative learning [83], collaborators can be explained as providing social and emotional support to each other, enjoying mutual interaction, and having a positive effect on satisfaction and results. Participants in our study felt motivated by their collaborator. A social psychological perspective considers motivation as a precursor to effective cognitive processes during collaborative learning. Motivation in collaborative learning can be viewed from two points of view. From a socio-motivational point of view, collaborators are motivated to work together because they 
share the rewards for completing the task. From a social cohesion point of view, cohesiveness arises between collaborators and draws them into looking after each other and cooperating and working together. Slavin [84] and Johnson and Johnson [85] discovered that students are more motivated during collaborative learning than individual learning.

Another important finding is that collaborators debated a lot during the problem-solving process and sought verification and consensus with their collaborator. From a cognitive perspective on collaborative learning [86], collaboration with a peer can be explained as achieving better quality in basic information processing components such as coding, rehearsal and retrieval of information, activation of strategies and metacognition. Participants in our study claimed it would have taken them longer to solve the tasks individually. O'Donnell and Dansereau [87] explain that the presence of collaborator helps the student stay focused on a task and gives them an opportunity to verify understanding of the subject matter.

According to Webb and Farivar [88], if a student explains the task to the collaborator, it allows the student to identify flaws in their own reasoning. Collaborative learning and negotiation of meaning between people can support greater coherence in understanding subject matter [89].

Participants also explained that finally seeing what contour lines represent in reality helped them gain insight. From the perspective of Piaget's theory of cognitive development, specifically of the concept of mental schemas [90], the educational tools implemented in our CIVE application, which enabled participants to switch between a 2D map and 3D model or to raise water level in the terrain, served as a means to confront the participant's understanding of the subject matter. In Piaget's terms, participants underwent the process of accommodation, during which their preexisting schemas were adjusted according to the new experience. The importance of experience was emphasized both by Piaget's predecessors as Dewey [91], and his followers, who further elaborated his work: Kolb [92] understands learning as a circular process of creating knowledge via transformation of experience. Participants in our study first tried to complete the task on a 2D map. Their assumptions and understanding were then challenged by the 3D model which visualized their solution. In the case of an incorrect solution, cognitive conflict or disequilibrium occurs as a result, which drives the student to reduce this state and to renew equilibrium. The collaborator serves as another potential source of cognitive conflict. This is in accordance with the general educational approach proposed by Neale, Smith, and Johnson [93], to first give students an opportunity to create assumptions about the subject matter and then let them test it against evidence to discover contradictions. This strategy aims to make students aware of their predictions and present contradictory evidence to create cognitive conflict.

The participants expressed that they had a better understanding of contour lines after the experiment. Several aspects could contribute to learning a skill to work with maps. One of them is from the perspective of Vygotsky's theory of cognitive development [94]. According to his concept of the zone of proximal development, if a student receives appropriate support during interaction with another person during the task solving process, they can internalize the process, reorganize cognitive structures, and develop new competence. This concept resembles the concept of scaffolding, which, according to Hogan and Pressley [95], is a support enabling a student to solve new tasks, teaches competence and fades over time. Modern usage of this term often incorporates not only interpersonal support but also software based educational tools. Our CIVE application provided scaffolding for learning through problem solving, which according to Guzdial et al. [96] helps students acquire deep understanding of subject matter and new competence. Our application was also a case of scientific discovery learning, which Chen and Zhang [97] consider as a learning process during which students generate and test their hypothesis. In their study, they found a prominent effect of collaborative scientific discovery learning in VR on intuitive understanding and discovery outcomes. The results of the study by Okada \& Simon [98] show that collaborative discovery learning in pairs is more effective compared to individual discovery learning.

Participants had problems with the absence of avatar faces and invisibility of emotions. According to Ekman and Friesen [99], people gather information about another person from four main 
sources in the visual informational channel: the face, tilts of the head, body posture, and skeletal muscle movements. They described that during conversation people do not continuously look at a listener but look to determine the listener's emotions or find out whether they are paying attention, agreeing, or attempting to respond with their own speaking. The participants of our study did not have a virtual face and could not make these distinctions. Some of them therefore did not even look at their collaborator's face while they were speaking. Most participants, however, missed having a face as a channel of information and did not know how to substitute its role.

Participants described their experiences with limited gestures via controllers and how they had to learn to work with it. Tu [100] explained that virtual communication differs from communication in objective reality. According to him, because of the limited communication channels, participants miss the clues for social context, and communication may be impersonal or cold. Virtual communication therefore requires different communication styles and strategies to maintain personal and social communication. In our study, we observed that participants sought personal contact with their collaborator, and even though the communication channels were limited, found innovative ways of using controllers and avatars for communication.

Participants described that having an intangible body created situations of obstructing each other's view but did not influence the proximity and personal space rules they followed. Bailenson et al. [101,102] discovered in several studies that participants seek to maintain the same interpersonal distance in immersive virtual reality as in objective reality. This is in accordance with our observations and what participants expressed in the focus group and interviews. They used their avatars as nonverbal communication tools and kept the same proximity to the collaborator as they would in objective reality. However, because they did not have full control over the avatar's movements and position, obstruction of each other's view sometimes occurred.

Some participants described strange sensations related to the cognitive discrepancy between their tactile sensations of objective reality and their visual perception of virtual reality. Some of them asked themselves Where are my legs? It is important, though, that this was not a case of cybersickness, which, according to LaViola [103] and Davis, Nesbitt, and Nalivaiko [104], is a type of motion sickness caused by cognitive discrepancy between the tactile sensations of a static position and the visual perception of movement. It seems, however, to be based on the same principle of cognitive discrepancy.

A common experience shared by participants was immersion and involvement in the artificial world. Witmer and Singer [105] describe immersion and involvement as preconditons for a sense of presence. Immersion as a psychological state can be characterized as perceiving the particular environment which surrounds us and perceiving self as a part of that environment. In the context of virtual reality, it means ignoring the medium and being absorbed by the simulation [106]. The participants of our study described losing track of objective reality and not knowing what was happening around them in objective reality. Involvement occurs as a result of being engaged in a meaningful task and focusing attention on specific content. Csikszentmihalyi's [107] well-known psychological concept of flow describes a similar state characterized by being fully involved and absorbed in a task, feeling energized focus and enjoyment, and losing a sense of time and space. The participants of our study described the task as capturing their whole attention and eliminating the perception of external stimuli. According to Witmer and Singer [105], participants feel a stronger sense of presence in virtual reality than objective reality as result of both immersion and involvement, which is precisely what out participants described.

Several participants in our study described their confusion during the return to objective reality. Two of the participants described states of derealization, which is defined by DSM-5 [83] as the detachment from a person's surroundings (world, people, or objects) and experience of the surroundings as unreal, dreamlike, or visually distorted. Research conducted by Aardema et al. [108] demonstrated that exposure to immersive VR induces a dissociative experience and temporarily increases the symptoms of depersonalization and derealization from objective reality. 


\section{Conclusions}

In this study, we explored the experience of geography learning in a CIVE. The experiment centered on collaborative learning, development of geography competences and cognitive and social aspects. The objective was to broaden knowledge and understanding of these areas in the specific context of a CIVE. Using a uniquely-developed geography learning CIVE application, twelve participants experienced an educational intervention during which they collaborated in pairs on geospatial tasks. By means of observation, semistructured interviews, a focus group, and an interpretative phenomenological analysis, we gained deep insight into the participants' experiences. From these data, four superordinate themes emerged, each including the above depicted subthemes.

From these superordinate themes, we concluded the following:

1. Appreciation for having a collaborator. Collaborative educational interventions have previously been shown as more efficient than individual task solving [85-87] (among others). Whether this applies to a VR environment is yet to be empirically tested at a quantitative level, but based on our study's results, we may conclude that collaborative VR education has great potential both in terms of improving learning outcomes and decreasing task related anxiety.

2. The Surprising "Fun with Maps". Motivational potential is believed to be one of the greatest expected advantages of VR educational interventions. As far as we can estimate from the qualitative analyses, when the topic of the educational session is well chosen, VR offers ways of exciting learners and making them interested in a topic they would find (or expect to be) boring. However, such a qualified choice needs to be based on the necessary knowledge of the lesson's subject (geography in our case), educational principles and VR technology specifics.

3. Communication as a challenge. As some participants reported that communication with their partner was challenging when no facial expressions were transmittable and because gestures were not precisely transferred into VR, the means of communication in a CIVE appear to be one of the key topics for future research. However, since we observed that many of the participants managed to innovate ways of communicating within a relatively short time (approx. 60-120 min), we believe that in a long-term educational intervention (for example, a regular semester course) learners would likely adapt and communication would no longer feel challenging. This is also yet to be confirmed experimentally.

4. Cognition in two realities. Since some of the participants reported negative or confused feelings after the VR session during their return to objective reality, some future research challenges have emerged. The first will be to eliminate the negative impact of VR immersion in some participants. Predictors of the depersonalization and derealization states need to be identified in order to provide special care to those learners at risk (or to exclude them from the intervention before they are allowed to begin). The second and a worthwhile consideration will be to search for ways of adapting the VR environment or sessions to decrease the risk of such states. However, most of the participants showed no indications of negative feelings, and hence, the overall results of our study are more than motivating for further elaboration of the CIVE intervention design.

This IPA-based study identified key areas that may play a key role in using collaborative iVR technology and suggested its potential benefits and limits in the field of education. In future studies, quantitative confirmation of the findings will be extensive and include effectiveness comparisons with traditional tools such as GIS (Parong \& Mayer) [109]. Broadening the list of learning tasks is also yet to be done. Challenges for further research will include the impact of intervening variables such as the level of user experience with iVR, educational intervention length (repeated measurements), and interindividual differences (e.g., cognitive style or map literacy).

Supplementary Materials: The following are available online at http://hci.fi.muni.cz/CIVE-papers/Task 1_Mirror_signals.mp4 (Video S1—task 1) http://hci.fi.muni.cz/CIVE-papers/Task_2_Flooded_valley.mp4 (Video S2-task 2). 
Author Contributions: Only the substantial activities are listed for each author. Conceptualization, Č.Š., Z.S., J.C., V.J. and P.K.; Data Curation, H.T.; Formal Analysis, M.S.; Funding Acquisition, H.S.; Investigation, H.T.; Methodology, Č.Š., Z.S., M.S. and T.U.; Project Administration, P.K.; Resources, L.H.; Software, J.C. and M.D.; Supervision, Č.Š., Z.S. and J.C.; Visualization, P.U.; Writing-Original Draft, M.S.; Writing-Review \& Editing, A.S.

Funding: This research was funded by Masaryk University, Czech Republic, Grant No. MUNI/M/0846/2015, "Influence of cartographic visualization methods on the success of solving practical and educational spatial tasks".

Acknowledgments: The authors would like to thank all students and colleagues who participated in this study. This work was supported by the research infrastructure of the HUME Lab Experimental Humanities Laboratory, Faculty of Arts, Masaryk University.

Conflicts of Interest: The authors declare no conflict of interest.

\section{References}

1. Romano, D.M. Virtual Reality Therapy. Dev. Med. Child Neurol. 2005, 47, 580. [CrossRef] [PubMed]

2. Botella, C.; García-Palacios, A.; Villa, H.; Baños, R.; Quero, S.; Alcañiz, M.; Riva, G. Virtual Reality Exposure in the Treatment of Panic Disorder and Agoraphobia: A controlled Study. Clin. Psychol. Psychother. 2007, 14, 164-175. [CrossRef]

3. Garcia-Palacios, A.; Hoffman, H.; Kwong See, S.; Tsai, A.; Botella, C. Redefining Therapeutic Success with Virtual Reality Exposure Therapy. CyberPsychol. Behav. 2001, 4, 341-348. [CrossRef] [PubMed]

4. Bertella, L.; Marchi, S.; Riva, G. Virtual Environment for Topographical Orientation (VETO): Clinical Rationale and Technical Characteristics. Presence Teleoperators Virtual Environ. 2001, 10, 440-449. [CrossRef]

5. Cho, B.H.; Ku, J.; Jang, D.P.; Kim, S.; Lee, Y.H.; Kim, I.Y.; Lee, J.H.; Kim, S.I. The Effect of Virtual Reality Cognitive Training for Attention Enhancement. Cyberpsychol. Behav. 2002, 5, 129-137. [CrossRef] [PubMed]

6. Anderson-Hanley, C.; Arciero, P.; Brickman, A.; Nimon, J.; Okuma, N.; Westen, S.; Merz, M.; Pence, B.; Woods, J.; Kramer, A.; et al. Exergaming and Older Adult Cognition. Am. J. Prevent. Med. 2012, 42, 109-119. [CrossRef]

7. Moller, H.J.; Bal, H.; Sudan, K.; Potwarka, L.R. Recreating Leisure: How Immersive Environments can Promote Wellbeing. In Interacting with Presence: HCI and the Sense of Presence in Computer-Mediated Environments; Riva, G., Waterworth, J., Murray, D., Eds.; De Gruyter Open Ltd.: Warsaw/Berlin, Germany, 2014; pp. 102-122.

8. Waterworth, J.; Waterworth, E.L. Relaxation Island: A Virtual Tropical Paradise. In Proceedings of the British Computer Society HCI Conference 2004: Designing for Life, Leeds, UK, 6-10 September 2004.

9. Keefe, F.; Huling, D.; Coggins, M.; Keefe, D.; Rosenthal, Z.; Herr, N.; Hoffman, H. Virtual Reality for Persistent Pain: A New Direction for Behavioral Pain Management. Pain 2012, 153, 2163-2166. [CrossRef]

10. Mirelman, A.; Maidan, I.; Herman, T.; Deutsch, J.; Giladi, N.; Hausdorff, J. Virtual Reality for Gait Training: Can It Induce Motor Learning to Enhance Complex Walking and Reduce Fall Risk in Patients With Parkinson's Disease? J. Gerontol. Ser. A Biol. Sci. Med. Sci. 2010, 66, 234-240. [CrossRef]

11. Huber, T.; Paschold, M.; Hansen, C.; Wunderling, T.; Lang, H.; Kneist, W. New Dimensions in Surgical Training: Immersive Virtual Reality Laparoscopic Simulation Exhilarates Surgical Staff. Surg. Endosc. 2017, 31, 4472-4477. [CrossRef]

12. Kilmon, C.A.; Brown, L.; Ghosh, S.; Mikitiuk, A. Immersive Virtual Reality Simulations in Nursing Education. Nurs. Educ. Perspect. 2010, 31, 314-317.

13. Ordaz, N.; Romero, D.; Gorecky, D.; Siller, H. Serious Games and Virtual Simulator for Automotive Manufacturing Education \& Training. Procedia Comput. Sci. 2015, 75, 267-274. [CrossRef]

14. Matsas, E.; Vosniakos, G. Design of a Virtual Reality Training System for Human-robot Collaboration in Manufacturing Tasks. Int. J. Interact. Design Manuf. 2015, 11, 139-153. [CrossRef]

15. El-Mounayri, H.; Rogers, C.; Fernandez, E.; Satterwhite, J. Assessment of STEM e-Learning in an Immersive Virtual Reality (VR) Environment. In Proceedings of the 2016 ASEE Annual Conference \& Exposition Proceedings, ASEE Conferences, New Orleans, LA, USA, 26-29 June 2016. [CrossRef]

16. Guttentag, D. Virtual Reality: Applications and implications for tourism. Tour. Manag. 2010, 31, 637-651. [CrossRef] 
17. Callieri, M.; Chica, A.; Dellepiane, M.; Besora, I.; Corsini, M.; Moyés, J.; Ranzuglia, G.; Scopigno, R.; Brunet, P. Multiscale Acquisition and Presentation of very Large Artifacts. J. Comput. Cultural Heritage 2011, 3, 1-20. [CrossRef]

18. Jung, T.H.; tom Dieck, M.C. Augmented Reality, Virtual Reality and 3D Printing for the Co-Creation of Value for the Visitor Experience at Cultural Heritage Places. J. Place Manag. Dev. 2017, 10, 140-151. [CrossRef]

19. De la Peña, N.; Weil, P.; Llobera, J.; Spanlang, B.; Friedman, D.; Sanchez-Vives, M.; Slater, M. Immersive Journalism: Immersive Virtual Reality for the First-Person Experience of News. Presence Teleoperators Virtual Environ. 2010, 19, 291-301. [CrossRef]

20. Bideau, B.; Kulpa, R.; Vignais, N.; Brault, S.; Multon, F.; Craig, C. Virtual reality, a Serious Game for Understanding Performance and Training Players in Sport. IEEE Comput. Gr. Appl. 2009. [CrossRef]

21. Staurset, E.; Prasolova-Førland, E. Creating a Smart Virtual Reality Simulator for Sports Training and Education. Smart Innov. Syst. Technol. 2016, 59, 423-433.

22. Mól, A.C.; Jorge, C.A.; Couto, P.M. Using a Game Engine for VR Simulations in Evacuation Planning. IEEE Comput. Gr. Appl. 2008, 28, 6-12. [CrossRef]

23. Shen, S.; Gong, J.; Liang, J.; Li, W.; Zhang, D.; Huang, L.; Zhang, G. A Heterogeneous Distributed Virtual Geographic Environment-Potential Application in Spatiotemporal Behavior Experiments. ISPRS Int. J. Geo-Inf. 2018, 7, 54. [CrossRef]

24. Cook, D.; Cruz-Neira, C.; Kohlmeyer, B.D.; Lechner, U.; Lewin, N.; Nelson, L.; Olsen, A.; Pierson, S.; Symanzik, J. Exploring Environmental Data in a Highly Immersive Virtual Reality Environment. Environ. Monit. Assess. 1998, 51, 441-450. [CrossRef]

25. Kreylos, O.; Bawden, G.; Bernardin, T.; Billen, M.I.; Cowgill, E.S.; Gold, R.D.; Hamann, B.; Jadamec, M.; Kellogg, L.H.; Staadt, O.G.; et al. Enabling scientific workflows in virtual reality. In Proceedings of the 2006 ACM international conference on Virtual reality continuum and its applications, VRCIA '06, Hong Kong, China, 14-17 June 2006; ACM: New York, NY, USA, 2006; pp. 155-162. [CrossRef]

26. Lin, H.; Gong, J. Exploring Virtual Geographic Environments. Geogr. Inf. Sci. 2001, 7, 1-7. [CrossRef]

27. Kubíček, P.; Šašinka, Č.; Stachoň, Z.; Herman, L.; Juřík, V.; Urbánek, T.; Chmelík, J. Identification of altitude profiles in 3D geovisualizations: The role of interaction and spatial abilities. Int. J. Dig. Earth 2017, 1-17. [CrossRef]

28. Carbonell-Carrera, C.; Saorín, J. Geospatial Google Street View with Virtual Reality: A Motivational Approach for Spatial Training Education. ISPRS Int. J. Geo-Inf. 2017, 6, 261. [CrossRef]

29. Virtanen, J.; Hyyppä, H.; Kämäräinen, A.; Hollström, T.; Vastaranta, M.; Hyyppä, J. Intelligent Open Data 3D Maps in a Collaborative Virtual World. ISPRS Int. J. Geo-Inf. 2015, 4, 837-857. [CrossRef]

30. Zanola, S.; Fabrikant, S.I.; Çöltekin, A. The Effect of Realism on the Confidence in Spatial Data Quality in Stereoscopic 3D Displays. In Proceedings of the 24th International Cartography Conference, ICC 2009, Santiago, Chille, 15-21 November 2009; pp. 15-21.

31. Zhang, S.; Moore, A. The Usability of Online Geographic Virtual Reality for Urban Planning. ISPRS-International Archives of the Photogrammetry. Remote Sens. Spat. Inf. Sci. 2013, XL-2/W2, 145-150. [CrossRef]

32. Abulrub, A.; Attridge, A.; Williams, M. Virtual Reality in Engineering Education: The Future of Creative Learning. Int. J. Emerg. Technol. Learn. 2011, 6. [CrossRef]

33. Dinis, F.M.; Guimaraes, A.S.; Carvalho, B.R.; Martins, J.P.P. Development of Virtual Reality Game-based Interfaces for Civil Engineering Education. In Proceedings of the 2017 IEEE Global Engineering Education Conference, EDUCON, Athens, Greece, 26-28 April 2017; pp. 1195-1202. [CrossRef]

34. Lalley, J.P.; Piotrowski, P.S.; Battaglia, B.; Brophy, K.; Chugh, K. A Comparison of V-Frog[C] to Physical Frog Dissection. Int. J. Environ. Sci. Educ. 2010, 5, 189-200.

35. Ai-Lim Lee, E.; Wong, K.; Fung, C. How Does Fesktop Virtual Reality Enhance Learning Outcomes? A Structural Equation Modeling Approach. Comput. Educ. 2010, 55, 1424-1442. [CrossRef]

36. Lee, B.W.; Shih, H.Y.; Chou, Y.T.; Chen, Y.S. Educational Virtual Reality Implementation on English for Tourism Purpose Using Knowledge-based Engineering. In Proceedings of the 2017 International Conference on Applied System Innovation, ICASI, Sapporo, Japan, 13-17 May 2017; pp. 792-795. [CrossRef]

37. Lai, C.; McMahan, R.P.; Kitagawa, M.; Connolly, I. Geometry Explorer: Facilitating Geometry Education with Virtual Reality. In Virtual, Augmented and Mixed Reality; Springer International Publishing: Cham, Switzerland, 2016; pp. 702-713. [CrossRef] 
38. Molka-Danielsen, J.; Prasolova-Førland, E.; Fominykh, M.; Lamb, K. Reflections on Design of Active Learning Module for Training Emergency Management Professionals in Virtual Reality. In NOKOBIT—Norsk Konferanse for Organisasjoners Bruk av Informasjonsteknologi; NOKOBIT, Bibsys Open Journal Systems: Oslo, Norway, 2017; Volume 25, p. 1.

39. Van der Linden, A.; van Joolingen, W. A Serious Game for Interactive Teaching of Newton's Laws. In Proceedings of the 3rd Asia-Europe Symposium on Simulation \& Serious Gaming-VRCAI '16, New York, NY, USA, 3-4 December 2016; pp. 165-167. [CrossRef]

40. Ştefan, L. Immersive Collaborative Environments for Teaching and Learning Traditional Design. Procedia Soc. Behav. Sci. 2012, 51, 1056-1060. [CrossRef]

41. Hirmas, D.; Slocum, T.; Halfen, A.; White, T.; Zautner, E.; Atchley, P.; Liu, H.; Johnson, W.; Egbert, S.; McDermott, D. Effects of Seating Location and Stereoscopic Display on Learning Outcomes in an Introductory Physical Geography Class. J. Geosci. Educ. 2014, 62, 126-137. [CrossRef]

42. Stojšić, I.; Ivkov Džigurski, A.; Maričić, O.; Ivanović Bibić, L.; Đukičin Vučković, S. Possible Application of Virtual Reality in Geography Teaching. J. Subj. Didact. 2017, 1, 83-96. [CrossRef]

43. Konečný, M. Cartography: Challenges and Potential in the Virtual Geographic Environments Era. Ann. GIS 2011, 17, 135-146. [CrossRef]

44. Herman, L.; Kvarda, O.; Stachoň, Z. Cheap and Immersive Virtual Reality: Application in Cartography. In ISPRS Archives of the Photogrammetry, Remote Sensing and Spatial Information Sciences; Zlatanova, S., Dragicevic, S., Sithole, G., Eds.; Copernicus GmbH: Gottingen, Germany, 2018; Volume XLII-4, pp. 261-266. [CrossRef]

45. Masrur, A.; Zhao, J.; Wallgrün, J.O.; LaFemina, P.; Klippel, A. Immersive Applications for Informal and Interactive Learning for Earth Science. In Proceedings of the Workshop on Immersive Analytics, Exploring Future Interaction and Visualization Technologies for Data Analytics, VIS2017, Phoenix, AZ, USA, 1-6 October 2017; pp. 1-5.

46. Hsu, W.C.; Lin, H.C.K.; Lin, Y.H. The research of applying Mobile Virtual Reality to Martial Arts learning system with flipped classroom. In Proceedings of the 2017 International Conference on Applied System Innovation, ICASI, Sapporo, Japan, 13-17 May 2017; pp. 1568-1571. [CrossRef]

47. Halabi, O.; Abou El-Seoud, S.; Alja'am, J.; Alpona, H.; Al-Hemadi, M.; Al-Hassan, D. Design of Immersive Virtual Reality System to Improve Communication Skills in Individuals with Autism. Int. J. Emerg. Technol. Learn. 2017, 12, 50. [CrossRef]

48. Fisher, P.; Unwin, D. Virtual Reality in Geography; Taylor and Francis Ltd.: London, UK, 2001.

49. Batty, M. Virtual Reality in Geographic Information Systems. In The Handbook of Geographic Information Science; Wilson, J.P., Fotheringham, A.S., Eds.; Blackwell Publishing: Oxford, UK, 2008; pp. 317-334.

50. Lin, H.; Chen, M.; Lu, G.; Zhu, Q.; Gong, J.; You, X.; Wen, Y.; Xu, B.; Hu, M. Virtual Geographic Environments (VGEs): A New Generation of Geographic Analysis Tools. Earth-Sci. Rev. 2013, 126, 74-84. [CrossRef]

51. Lin, H.; Batty, M.; Jorgensen, S.E.; Fu, B.; Konečný, M.; Voinov, A.A.; Torrens, P.; Lu, G.; Zhu, A.X.; Wilson, J.P.; et al. Virtual Environments Begin to Embrace Process-based Geographic Analysis. Trans. GIS 2015, 19, 493-498. [CrossRef]

52. Philips, A.; Walz, A.; Bergner, A.; Graeff, T.; Heistermann, M.; Kienzler, S.; Korup, O.; Lipp, T.; Schwanghart, W.; Zeilinger, G. Immersive 3D Geovisualization in Higher Education. J. Geogr. Higher Educ. 2015, 39, 437-449. [CrossRef]

53. Carbonell Carrera, C.; Saorin, J.L.P.; de la Torre Cantero, J. Teaching with AR as a Tool for Relief Visualization: Usability and Motivation Study. Int. Res. Geogr. Environ. Educ. 2017, 27, 69-84. [CrossRef]

54. Merchant, Z.; Goetz, E.; Cifuentes, L.; Keeney-Kennicutt, W.; Davis, T. Effectiveness of Virtual Reality-based Instruction on Students' Learning Outcomes in K-12 and Higher Education: A Meta-analysis. Comput. Educ. 2014, 70, 29-40. [CrossRef]

55. Zyda, M. From Visual Simulation to Virtual Reality to Games. Computer 2005, 38, 25-32. [CrossRef]

56. Gee, J. What Video Games Have to Teach us About Learning and Literacy; Palgrave Macmillan: Basingstoke, UK, 2008.

57. Ang, C.S.; Rao, G.S.V.R.K. Computer Game Theories for Designing Motivating Educational Software: A Survey Study. Int. J. E-Learn. 2008, 7, 181-199. 
58. Kyndt, E.; Raes, E.; Lismont, B.; Timmers, F.; Cascallar, E.; Dochy, F. A Meta-analysis of the Effects of Face-to-face Cooperative Learning. Do Recent Studies Falsify or Verify Earlier Findings? Educ. Res. Rev. 2013, 10, 133-149. [CrossRef]

59. Harding-Smith, T. Learning Together: An Introduction to Collaborative Learning; HarperCollins College Publishers: New York, NY, USA, 1993.

60. Vygotsky, L. Interaction between Learning and Development; W.H. Freeman and Company: New York, NY, USA, 1997.

61. Dillenbourg, P. Collaborative Learning: Cognitive and Computational Approaches; Advances in Learning and Instruction Series; Elsevier Science, Inc.: New York, NY, USA, 1999.

62. Gokhale, A.A. Collaborative Learning Enhances Critical Thinking. J. Technol. Educ. 1995, 7, 22-30. [CrossRef]

63. Havenith, H.-B.; Cerfontaine, P.; Mreyen, A.-S. How Virtual Reality Can Help Visualise and Assess Geohazards. Int. J. Digit. Earth 2017. [CrossRef]

64. Lin, H.; Chen, M.; Lu, G. Virtual Geographic Environment: A Workspace for Computer-Aided Geographic Experiments. Ann. Assoc. Am. Geogr. 2013, 103, 465-482. [CrossRef]

65. Lehtinen, E.; Hakkarainen, K.; Lipponen, L.; Veermans, M.; Muukkonen, H. Computer Supported Collaborative Learning: A Review. JHGI Giesbers Rep. Educ. 1999, 10, 1999.

66. Jackson, R.L.; Fagan, E. Collaboration and learning within immersive virtual reality. In Proceedings of the 3rd International Conference on Collaborative Virtual Environments; Churchill, E., Reddy, M., Eds.; ACM: New York, NY, USA, 2000; pp. 83-92. [CrossRef]

67. He, T.; Chen, X.; Chen, Z.; Li, Y.; Liu, S.; Hou, J.; He, Y. Immersive and Collaborative Taichi Motion Learning in Various VR Environments. In Proceedings of the 2017 IEEE Virtual Reality (VR), Los Angeles, CA, USA, 18-22 March 2017; IEEE: Los Angeles, CA, USA, 2017; pp. 307-308. [CrossRef]

68. Kaufmann, H.; Schmalstieg, D. Designing Immersive Virtual Reality for Geometry Education. In Proceedings of the IEEE Virtual Reality Conference (VR 2006), Alexandria, VA, USA, 25-29 March 2006; pp. 51-58. [CrossRef]

69. Dos Reis, P.R.; Matos, C.E.; Diniz, P.S.; Silva, D.M.; Dantas, W.; Braz, G.; de Paiva, A.C.; Araújo, A.S. An Immersive Virtual Reality Application for Collaborative Training of Power Systems Operators. In Proceedings of the 2015 XVII Symposium on Virtual and Augmented Reality, Sao Paulo, Brazil, 25-28 May 2015; pp. 121-126. [CrossRef]

70. Siemens, G. Connectivism: A Learning Theory for the Digital Age. Int. J. Instruct. Technol. Distance Learn. 2014, 2, 1-8.

71. Horvath, I. Innovative Engineering Education in the Cooperative VR Environment. In Proceedings of the 2016 7th IEEE International Conference on Cognitive Infocommunications, CogInfoCom, Wroclaw, Poland, 16-18 October 2016; pp. 359-364. [CrossRef]

72. Hew, K.; Cheung, W. Use of Three-dimensional (3-D) Immersive Virtual Worlds in K-12 and Higher Education Settings: A Review of the Research. Br. J. Educ. Technol. 2010, 41, 33-55. [CrossRef]

73. Doležal, M.; Chmelík, J.; Liarokapis, F. An Immersive Virtual Environment for Collaborative Geovisualization. In Proceedings of the 9th International Conference on Virtual Worlds and Games for Serious Applications, VS-Games 2017, Athens, Greece, 6-8 September 2017; pp. 272-275. [CrossRef]

74. Juřík, V.; Herman, L.; Kuníček, P.; Stachoň, Z.; Šašinka, Č. Cognitive Aspects of Collaboration in 3D Virtual Environments. In ISPRS Archives of the Photogrammetry, Remote Sensing and Spatial Information Sciences; Halounova, L., Ed.; Copernicus GmbH: Gottingen, Germany, 2016; Volume XLI-B2, pp. 663-670. [CrossRef]

75. Symeonides, R.; Childs, C. The Personal Experience of Online Learning: An Interpretative Phenomenological Analysis. Comput. Hum. Behav. 2015, 51, 539-545. [CrossRef]

76. Smith, J.A.; Flowers, P.; Larkin, M. Interpretative Phenomenological Analysis: Theory, Method and Research; Sage Publications Ltd.: London, UK, 2009.

77. Reid, K.; Flowers, P.; Larkin, M. Exploring Lived Experience. Psychologist 2005, 18, $20-23$.

78. Smith, J.A.; Jarman, M.; Osborn, M. Doing Interpretative Phenomenological Analysis. In Qualitative Health Psychology; Murray, M., Chamberlain, K., Eds.; Sage Publications Ltd.: London, UK, 1999; pp. 218-240.

79. Gorard, S.; Taylor, C. Combining Methods in Educational and Social Research; Open University Press: Berkshire, UK, 2004.

80. Brannen, J. Combining Qualitative and Quantitative Approaches: An Overview. In Mixing Methods: Qualitative and Quantitative Research; Brannen, J., Ed.; Avebury: Aldershot, UK, 1992. 
81. Smith, J.A.; Osborn, M. Interpretative Phenomenological Analysis. In Qualitative Psychology: A Practical Guide to Research Methods; Smith, J.A., Ed.; Sage Publications Ltd.: London, UK, 2003; pp. 53-80.

82. Smith, J.A. Reflecting on the Development of Interpretative Phenomenological Analysis and its Contribution to Qualitative Research in Psychology. Qual. Res. Psychol. 2004, 1, 39-54.

83. O'Donnell, A.M.; Hmelo-Silver, C.E. Introduction What is Collaborative Learning?: An Overview. In The International Handbook of Collaborative Learning; Routledge: New York, NY, USA, 2013; pp. 13-28.

84. Slavin, R. When Does Cooperative Learning Increase Student Achievement? Psychol. Bull. 1983, 94, 429-445. [CrossRef]

85. Johnson, D.; Johnson, R. Making Cooperative Learning Work. Theory Pract. 1999, 38, 67-73. [CrossRef]

86. O'Donnell, A.M.; Dansereau, D.F.; Hythecker, V.I.; Larson, C.O.; Rocklin, T.R.; Lambiotte, J.G.; Young, M.D. The Effects of Monitoring on Cooperative Learning. J. Exp. Educ. 1986, 54, 169-173. [CrossRef]

87. O'Donnell, A.M.; Dansereau, D.F. Scripted Cooperation in Student Dyads: A Method for Analyzing and Enhancing Academic Learning and Performance. In Interaction in Cooperative Groups: The Theoretical Anatomy of Group Learning; Hertz-Lazarowitz, R., Miller, N., Eds.; Cambridge University Press: Cambridge, UK, 1992; pp. 120-141.

88. Webb, N.; Farivar, S. Promoting Helping Behavior in Cooperative Small Groups in Middle School Mathematics. Am. Educ. Res. J. 1994, 31, 369. [CrossRef]

89. Duschl, R.; Osborne, J. Supporting and Promoting Argumentation Discourse in Science Education. Stud. Sci. Educ. 2002, 38, 39-72. [CrossRef]

90. Piaget, J. The Psychology of Intelligence; Taylor \& Francis: London, UK, 2005; ISBN 0-203-98152-9.

91. Dewey, J. Experience and Education; Macmillan: New York, NY, USA, 1938.

92. Kolb, D. Experiential Learning, 2nd ed.; Pearson Education: Upper Saddle River, NJ, USA, 2015.

93. Neale, D.; Smith, D.; Johnson, V. Implementing Conceptual Change Teaching in Primary Science. Elem. Sch. J. 1990, 91, 109-131. [CrossRef]

94. Vygotsky, L.S. Mind in Society: The Development of Higher Psychological Processes; Harvard University Press: Cambridge, MA, USA, 1979.

95. Hogan, K.; Pressley, M. Scaffolding Scientific Competencies within Classroom Communities of Inquiry. In Advances in Learning \& Teaching. Scaffolding Student Learning: Instructional Approaches and Issues; Hogan, K., Pressley, M., Eds.; Brookline Books: Cambridge, MA, USA, 2017; pp. 74-107.

96. Guzdial, M.; Kolodner, J.; Hmelo, C.; Narayanan, H.; Carlson, D.; Rappin, N.; Hübscher, R.; Turns, J.; Newstetter, W. Computer support for learning through complex problem solving. Commun. ACM 1996, 39, 43-45. [CrossRef]

97. Chen, Q.; Zhang, J. 2 Collaborative Discovery Learning Based on Computer Simulation. In Collaborative Learning, Reasoning and Technology, 2nd ed.; O'Donnell, A., Hmelo-Silver, C.E., Erkens, G., Eds.; Routledge: New York, NY, USA, 2012; pp. 154-196.

98. Okada, T.; Simon, H. Collaborative Discovery in a Scientific Domain. Cognit. Sci. 1997, 21, $109-146$. [CrossRef]

99. Ekman, P.; Friesen, W. Unmasking the Face; Malor Books: Cambridge, MA, USA, 2003.

100. Tu, C.H. Online Collaborative Learning Communities: Twenty-one Designs to Building an Online Collaborative Learning Community; Libraries Unlimited: Westport, Ireland, 2004.

101. Bailenson, J.; Blascovich, J.; Beall, A.; Loomis, J. Equilibrium Theory Revisited: Mutual Gaze and Personal Space in Virtual Environments. Presence Teleoperators Virtual Environ. 2001, 10, 583-598. [CrossRef]

102. Bailenson, J.; Blascovich, J.; Beall, A.; Loomis, J. Interpersonal Distance in Immersive Virtual Environments. Personal. Soc. Psychol. Bull. 2003, 29, 819-833. [CrossRef] [PubMed]

103. LaViola, J. A Discussion of Cybersickness in Virtual Environments. ACM Sigchi Bull. 2000, 32, 47-56. [CrossRef]

104. Davis, S.; Nesbitt, K.; Nalivaiko, E. A Systematic Review of Cybersickness. In Proceedings of the 2014 Conference on Interactive Entertainment, IE2014, Newcastle, Australia, 2-3 December 2014; Blackmore, K., Nesbitt, K., Smith, S.P., Eds.; ACM: New York, NY, USA, 2014. [CrossRef]

105. Witmer, B.; Singer, M. Measuring Presence in Virtual Environments: A Presence Questionnaire. Presence Teleoperators Virtual Environ. 1998, 7, 225-240. [CrossRef]

106. Cruz-Neira, C.; Sandin, D.; DeFanti, T.; Kenyon, R.; Hart, J. The CAVE: Audio Visual Experience Automatic Virtual Environment. Commun. ACM 1992, 35, 64-72. [CrossRef] 
107. Csikszentmihaiyi, M. Flow: The Psychology of Optimal Experience; Harper \& Row Publishers: New York, NY, USA, 1990.

108. Aardema, F.; O'Connor, K.; Côté, S.; Taillon, A. Virtual Reality Induces Dissociation and Lowers Sense of Presence in Objective Reality. Cyberpsychol. Behav. Soc. Netw. 2010. [CrossRef] [PubMed]

109. Parong, J.; Mayer, R.E. Learning Science in Immersive Virtual Reality. J. Educ. Psychol. 2018, 110, $785-797$. [CrossRef]

(c)

(C) 2018 by the authors. Licensee MDPI, Basel, Switzerland. This article is an open access article distributed under the terms and conditions of the Creative Commons Attribution (CC BY) license (http://creativecommons.org/licenses/by/4.0/). 